\title{
(C) OPEN ACCESS \\ The role of IL-17A in axial spondyloarthritis and psoriatic arthritis: recent advances and controversies
}

\author{
Dennis G McGonagle, ${ }^{1,2}$ Iain B McInnes, ${ }^{3}$ Bruce W Kirkham, ${ }^{4}$ Jonathan Sherlock, ${ }^{5,6}$ \\ Robert Moots ${ }^{\oplus, 8}$
}

\begin{abstract}
Handling editor Josef $S$
Smolen

${ }^{1}$ Leeds Institute of Rheumatic and Musculoskeletal Medicine, University of Leeds, Leeds, UK ${ }^{2}$ NIHR Leeds Musculoskeletal Biomedical Research Unit,

Chapel Allerton, Leeds Teaching Hospital Trust, Leeds, UK ${ }^{3}$ Institute of Infection Immunity and Inflammation, University of Glasgow, Glasgow, UK ${ }^{4}$ Rheumatology Department, Guy's and Saint Thomas' NHS Foundation Trust, London, UK ${ }^{5}$ Kennedy Institute of Rheumatology, University of Oxford, Oxford, UK

${ }^{6}$ Nuffield Department of Orthopaedics, Rheumatology and Musculoskeletal Sciences, University of Oxford, Oxford, UK ${ }^{7}$ Institute of Ageing and Chronic Disease, University of Liverpool, Liverpool, UK

${ }^{8}$ Department of Academic Rheumatology, Aintree University Hospital, Liverpool, UK
\end{abstract}

\section{Correspondence to} Dr Robert Moots, University of Liverpool Institute of Ageing and Chronic Disease, Liverpool, L9 7AL, UK;

r.j.moots@liverpool.ac.uk

Received 8 March 2019 Revised 17 May 2019 Accepted 14 June 2019 Published Online First 5 July 2019

\section{Check for updates}

(C) Author(s) (or their employer(s)) 2019. Re-use permitted under CC BY-NC. No commercial re-use. See rights and permissions. Published by BMJ.

To cite: McGonagle DG, Mclnnes IB, Kirkham BW, et al. Ann Rheum Dis 2019;78:1167-1178.

\section{ABSTRACT}

Although the pathogenic mechanisms underlying axial spondyloarthritis (axSpA) and psoriatic arthritis (PsA) are not fully elucidated, several lines of evidence suggest that immune responses mediated by interleukin 17A (IL-17A) play a pivotal role in both diseases. This is best highlighted by the significant clinical efficacy shown with inhibitors of IL-17A in treating axSpA and PsA. Nevertheless, a number of knowledge gaps exist regarding the role of IL-17A in the pathophysiology of spondyloarthritis in man, including its cellular origin, its precise role in discrete disease processes such enthesitis, bone erosion, and bone formation, and the reasons for the discrepant responses to IL-17A inhibition observed in certain other spondyloarthritis manifestations. In this review, we focus on the latest data from studies investigating the role of IL-17A in ankylosing spondylitis (AS) and PsA that build on existing and emerging scientific knowledge in the field. Key remaining research questions are also highlighted to guide future research.

\section{INTRODUCTION}

The spondyloarthritides (SpA) comprise related but phenotypically distinct inflammatory diseases including psoriatic arthritis (PsA), non-radiographic axial spondyloarthritis (nr-axSpA) and radiographic axSpA (ankylosing spondylitis (AS)), arthritis associated with inflammatory bowel disease (IBD), reactive arthritis, juvenile idiopathic arthritis and acute anterior uveitis. ${ }^{1-3}$ The $\mathrm{SpA}$ diseases share common immunological and inflammatory components and present with overlapping clinical phenotypes. ${ }^{4-7}$ Indeed, multiple genetic polymorphisms within the interleukin (IL)-23/17 axis have been implicated across SpA. ${ }^{8-11}$ Intriguingly, despite the clinical and genetic similarities, these disorders are showing emergent and unexpected heterogeneity with respect to IL-23/17 axis therapeutic manipulation, a topic addressed later in this article.

IL-17A, a member of the IL-17 superfamily of cytokines, is known to play an important role in SpA manifestations related to the skin, joints and entheses, as reflected by the suppression of disease activity seen with IL-17A inhibitors in psoriasis, PsA and AS. ${ }^{12-19}$ However, in other settings where IL-17 family members have been found at sites of disease, such as gut inflammation and uveitis, IL-17A inhibition is not beneficial. ${ }^{20-22}$ These discrepant responses illustrate the need for clearer understanding of the aetiology of these inflammatory diseases, particularly the role of the IL-17 family in the context of the tissue(s) affected. IL-17 research has accelerated rapidly, with nearly 10000 articles published on this topic in the last 5 years alone. In this article we highlight the latest breakthroughs that expand understanding of the role of IL-17A in both homoeostasis and in disease in axSpA and PsA.

\section{IL-17A PRODUCTION AND SIGNALLING}

The IL-17 superfamily consists of six ligands (IL-17A to IL-17F), which can bind to five receptor subtypes (IL-17RA to IL-17RE). The basic biology of most of the IL-17 superfamily has been reviewed extensively elsewhere. ${ }^{23} 24$ IL-17A, the prototypical ligand, is by far the best characterised member of the IL-17 family and can exist as a homodimer or in a heterodimer with IL-17F and signals through an obligate dimeric IL-17RA and IL-17RC receptor complex. ${ }^{24}$ On binding to a receptor, IL-17A upregulates inflammatory gene expression either by inducing de novo gene transcription or by stabilising mRNA of pro-inflammatory cytokines and chemokines. $^{24}$

\section{WELL-DEFINED ROLE OF IL-17A IN HOST DEFENCE}

In healthy individuals, IL-17A, as well as other members of the IL-17 family, functions in host defence against a range of bacterial and fungal pathogens at epithelial and mucosal barriers in the skin, colon and airways. ${ }^{25-27}$ Although the exact interplay between the various IL-17 family members is poorly understood, epithelial cell-derived (especially IL-17C) and haematopoietic cell-derived IL-17s (IL-17A and F) may have complementary functions in response to pathogens, with the former predominantly enhancing barrier function and the latter propagating the inflammatory response. ${ }^{28}$ The IL-23/17 axis co-ordinates barrier function in the skin and the gut, both of which are sites of either physical or chemical stress and are also sites of complex microbiotal interactions. What might the common denominator be between the IL-23/17 axis and inflammation at the sterile skeletal locations afflicted by $\mathrm{SpA}$-associated pathology? We agree with the assertion that the IL-23/17 axis might be adapted to facilitate homoeostasis at these highly mechanically stressed entheseal sites that are prone to microinjury. ${ }^{29}$

An array of genetic defects in the IL-17 pathway, identified through human translational immunology, collectively point towards a role in antifungal immunity (table 1). Chronic mucocutaneous candidiasis (CMC) is a hallmark of individuals with genetic defects affecting IL-17 immunity, manifesting as recurrent or persistent infections of the skin, nails and mucosae with Candida albicans, with or without other clinical signs. ${ }^{30}$ As can be 


\begin{tabular}{|c|c|c|c|c|}
\hline Disease & Genes/proteins involved & Common infections & Effect on IL-23/IL-17 signalling & References \\
\hline \multirow[t]{5}{*}{ MSMD } & IL-12Rß1 & $\begin{array}{l}\text { Mycobacterium } \\
\text { tuberculosis, salmonella, candida } \\
\text { albicans }\end{array}$ & \multirow[t]{5}{*}{$\begin{array}{l}\text { Impaired IFN- } \gamma \text {-mediated immunity } \\
\text { Decreased IL-17A-producing T cells } \\
\text { Impaired IL-12 signalling }\end{array}$} & \multirow[t]{5}{*}{$176181183-187189$} \\
\hline & IL-12 $\beta$ & $\begin{array}{l}\text { Mycobacterium } \\
\text { tuberculosis, salmonella }\end{array}$ & & \\
\hline & $\mathrm{IFN}-\gamma \mathrm{R} 1$ & $\begin{array}{l}\text { Mycobacterium } \\
\text { tuberculosis, salmonella, candida } \\
\text { albicans }\end{array}$ & & \\
\hline & STAT1 & Mycobacterium, candida albicans & & \\
\hline & IL-12/23 p40 & $\begin{array}{l}\text { Mycobacterium } \\
\text { tuberculosis, salmonella }\end{array}$ & & \\
\hline \multirow[t]{3}{*}{ Salmonella infection } & IL-23R & Salmonella & \multirow[t]{3}{*}{ Th17 depletion, reduced production of IL-17A } & \multirow[t]{3}{*}{188190} \\
\hline & IL-12/23p40 & & & \\
\hline & IL-12R $\beta 1$ & & & \\
\hline \multirow[t]{6}{*}{ CMCD } & STAT1 & Candida albicans, mycobacterium & \multirow{6}{*}{$\begin{array}{l}\text { Reduced production of IL-17A, IL-17F, IL-22 } \\
\text { No response to IL-17A; reduced response to } \\
\text { IL-17F; IL-17E response maintained } \\
\text { Impaired neutrophil function }\end{array}$} & \multirow[t]{6}{*}{182183191193202} \\
\hline & CARD9 & Candida albicans & & \\
\hline & IL-17RA & $\begin{array}{l}\text { Candida albicans } \\
\text { Staphylococcus }\end{array}$ & & \\
\hline & IL-17RC & Candida albicans & & \\
\hline & IL-17F & Candida albicans & & \\
\hline & ACT1 & $\begin{array}{l}\text { Candida albicans } \\
\text { Staphylococcus }\end{array}$ & & \\
\hline APECED & AIRE & Candida albicans & $\begin{array}{l}\text { Increased autoantibodies to IL-17A, IL-17F, } \\
\text { and IL-22 }\end{array}$ & 194197 \\
\hline \multirow[t]{3}{*}{ HIES } & STAT3 & $\begin{array}{l}\text { Candida albicans, staphylococcus, } \\
\text { aspergillus }\end{array}$ & \multirow{3}{*}{$\begin{array}{l}\text { Increased serum IgE } \\
\text { Eosinophilia } \\
\text { Impaired development of Th17 cells } \\
\text { Reduced IL-17A production }\end{array}$} & \multirow[t]{3}{*}{49198201203} \\
\hline & DOCK8 & $\begin{array}{l}\text { Candida albicans, staphylococcus, } \\
\text { aspergillus }\end{array}$ & & \\
\hline & TYK2 & $\begin{array}{l}\text { Staphylococcus, mycobacterium, } \\
\text { salmonella }\end{array}$ & & \\
\hline
\end{tabular}

The genes and proteins involved and the resultant effects on IL-17 signalling that lead to increased susceptibility to certain infections are listed. $.^{49} 176-201$ IL-12 and IL-23 share cytokine and receptor subunits and the association with mycobacterial disease is thought to represent an effect on dysregulated IFN gamma production in the IL-12 pathway. Therefore IL-17 blockers or IL-23 p19 subunit blockers are not expected to have a link with mendelian susceptibility to mycobacterial disease.

AIRE, autoimmune regulator; APECED, autoimmune polyendocrinopathy-candidiasis-ectodermal dystrophy; CARD9, caspase recruitment domain-containing protein 9; CMCD, chronic mucocutaneous candidiasis disease; DOCK8, dedicator of cytokinesis 8; HIES, hyper IgE syndrome; IFN, interferon; IFN- $\gamma$ R1, interferon gamma receptor 1; IL-12Rß1, interleukin 12 receptor $\beta 1$; MSMD, Mendelian susceptibility to mycobacterial disease; STAT, signal transducer and activator of transcription; TYK2, tyrosine kinase 2; Th-17, T helper 17 cell.

seen from table 1 , these syndromes result from genetic defects affecting several immune processes, with the commonality being that the defects involve more than one cytokine or immune function. The genetic defects that are often shared between the IL-12 and the IL-23 pathway that are upstream of the IL-17 pathway are not linked to fungal infection but may be linked to mycobacterial infections consequent to impaired interferon gamma signalling. ${ }^{31}$

Preclinical and ex vivo studies also implicate IL-17A in immunity against a range of other pathogens including bacteria such as Escherichia coli, fungi such as Cryptococcus neoformans, parasites such as Trypanosoma cruzi, and viruses such as influenza (reviewed in Matsuzaki and Umemura). ${ }^{28}$ Although as with all drugs that modulate immune response there is the potential for an increased infection risk with IL-17A inhibitors, clinical data show no risk from specific pathogens, with the exception of candidiasis. ${ }^{18} 192^{32-35}$ Reassuringly, no association between mycobacterial disease and blockade of IL-17A biological activity has been observed in man. ${ }^{34}$

\section{ROLE OF IL-17A IN SPA}

Although IL-17A cytokine expression has been detected in a multitude of autoimmune and autoinflammatory diseases, a key role in psoriasis, PsA and axSpA is evident.

\section{Genetics}

Although a detailed examination of the genetic basis of $\mathrm{SpA}$ is outside the scope of this article (reviewed in detail in Taams et $a l$ and Brown et al), ${ }^{1136}$ the strongest association with genetic susceptibility to axSpA and PsA lies within the MHC class I region and in particular the HLA-B27 region. ${ }^{8-10}$ Multiple immunological functions can be altered by these genetic associations, including several relevant to IL-17A signalling through activation of CD8+T cells and CD4+T cells. ${ }^{11}{ }^{37-40}$ Several single nucleotide polymorphisms in genes directly involved in IL-17 signalling have also been linked to AS and PsA (figure 1), including variants in the IL-12 p40 subunit, the IL-23 p19 subunit, the IL-23 receptor, IL-17A and IL-17RA. ${ }^{41-48}$ Additional susceptibility variants have been identified in genes encoding IL-17-related signalling molecules including TYK2, TRAF3IP2 and STAT $3.43444749-53$

\section{IL-17A production}

There has been significant interest in identifying the sources of IL-17A in SpA and a number of innate and adaptive immune system cell types have been implicated (reviewed in Taams et al) (figure 2). ${ }^{11}$ Increased levels of type 3 innate lymphoid cells (ILC3) have been identified in blood and synovia of patients 


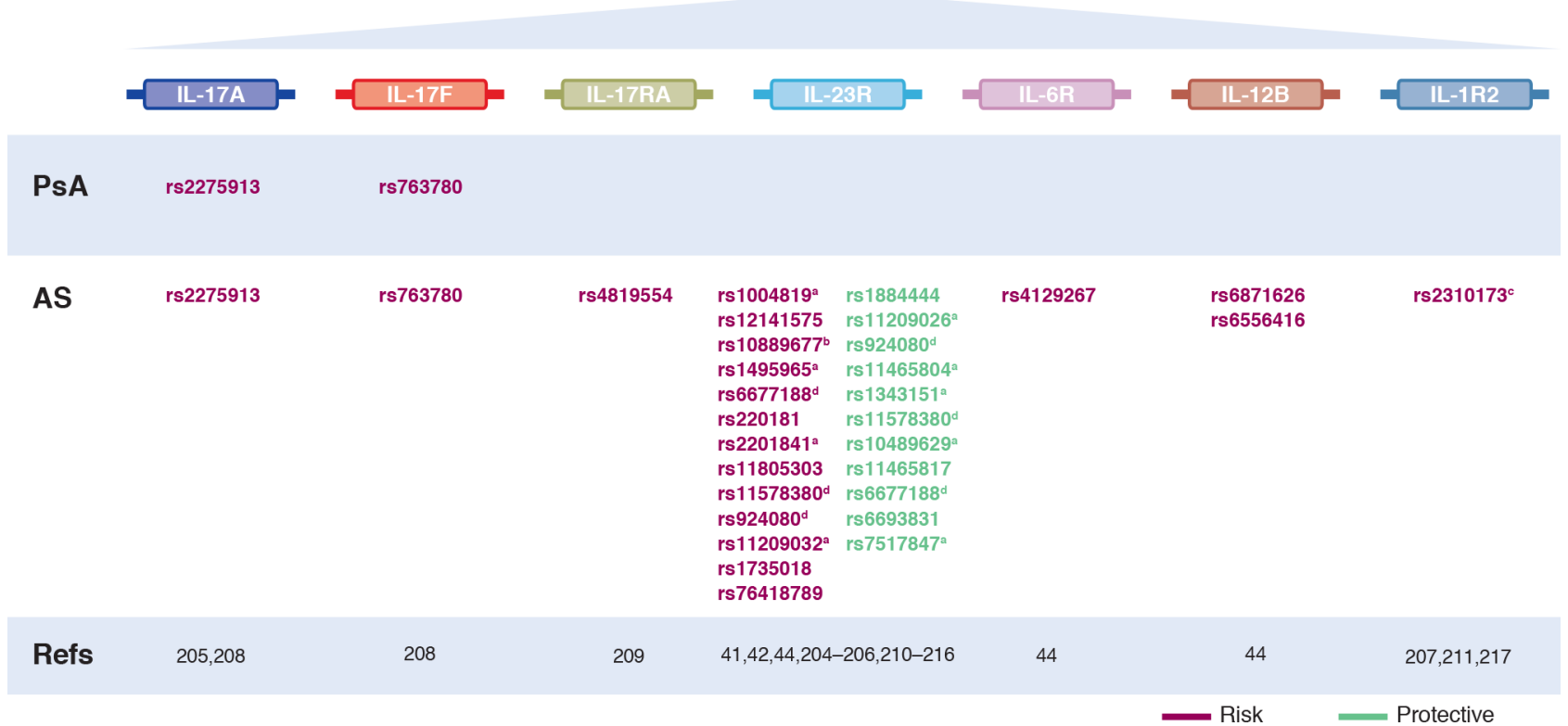

Figure 1 Single nucleotide polymorphisms identified in the IL-17 signalling pathway that have been linked to axial spondyloarthritis and psoriatic

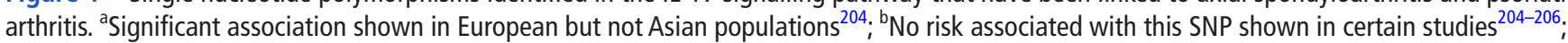
${ }^{C}$ No risk associated with this SNP shown in certain studies ${ }^{207} ;{ }^{d} S N P$ can be associated with risk or protection depending on the specific mutation. AS, ankylosing spondylitis; IL-1R2, interleukin 1 receptor; IL-6R, interleukin 6 receptor; IL17R, interleukin receptors; PsA, psoriatic arthritis; SNP, single nucleotide polymorphism.

with $\mathrm{SpA}$, and these levels correlate with PsA disease activity. ${ }^{54} 55$ Recently, resident populations of both ILC3 and $\gamma \delta$ T cells have been identified at the human enthesis for the first time where they may produce the IL-17A that drives enthesitis, a key early pathological lesion in SpA. ${ }^{56-59}$ Recent studies have also reported increased numbers of IL-17+invariant natural killer T (iNKT) cells and $\gamma \delta \mathrm{T}$ cells in SpA patient peripheral blood. ${ }^{60}$ Indeed, these ROR $\gamma t+$ innate like T cells, and not conventional T cells, represented about half of all IL-17 producing blood circulating T cells and were further skewed towards IL-17 expressing subsets

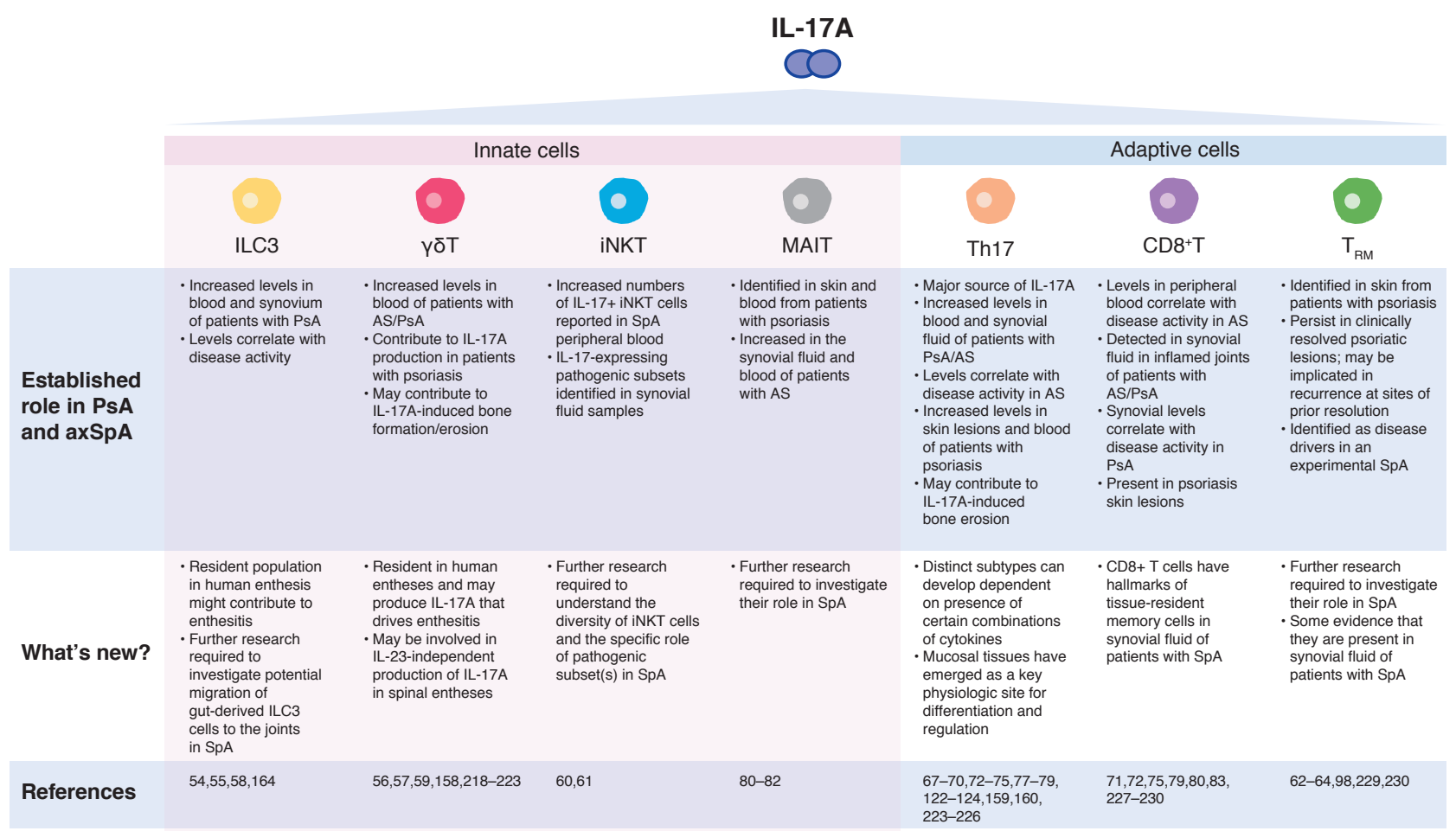

Figure 2 Key sources of IL-17A in spondyloarthritis. AS, ankylosing spondylitis; ILC3, type 3 innate lymphoid cell; iNKT, innate natural killer T cell; MAIT, mucosal-associated invariant T cell; PsA, psoriatic arthritis; SpA, spondyloarthritis; Th17, T helper 17 cell; $\mathrm{T}_{\mathrm{RM}}{ }^{\prime}$, resident memory T cell. 
in synovial fluid samples, as determined by both advanced cytometric methodologies and intracellular cytokine IL-17 staining. ${ }^{60}$ In vivo evidence for enrichment of pathogenic subsets in the joints was recently shown in mannan-induced arthritis in SKG mice, an IL-23/17 axis dependent disease. ${ }^{61}$

Tissue-resident memory $\mathrm{T}$ cells $\left(\mathrm{T}_{\mathrm{RM}}\right)$ represent approximately $50 \%-70 \%$ of the pool of resident $\mathrm{T}$ cells in healthy skin, and can produce a variety of cytokines, including IL-17A. ${ }^{62-64}$ In patients with psoriasis, IL-17-producing CD8 $+\mathrm{T}_{\mathrm{RM}}$ cells have been identified in non-involved skin and may be involved in recurrence of psoriasis at sites of prior resolution. ${ }^{62-64}$ Efforts are ongoing to investigate the role of $T_{R M}$ cells in tissues affected by SpA. A study in patients with PsA has shown the presence of IL-17 expressing CD4- $(\mathrm{CD} 8+) \mathrm{T}$ cells in the synovium. ${ }^{65}$ However, no studies have been reported in axial disease to date.

Adaptive immune cells are key drivers of chronicity in SpA and as such, are also a major source of IL-17A. The presence of T helper 17 (Th17) cells in SpA is relatively well established. ${ }^{66}$ Increased levels of both Th17 cells and IL-17A are found in skin lesions and the blood of patients with psoriasis as well as the blood and synovial fluid of patients with AS and PsA. ${ }^{67-75}$ IL-17A initiates several feedback-loop mechanisms in SpA leading to increased expansion of Th17 cells and thereby further production of IL-17A. ${ }^{76}$ Evidence suggests that there are distinct subtypes of Th17 cells whose differentiation is dependent on specific combinations of cytokines. ${ }^{77}$ Furthermore, there is likely to be considerable plasticity between Th17 cells and FOXP3+regulatory $\mathrm{T}$ cells. ${ }^{78}$ Identification of the subtype(s) of Th17 cells and their regulation and relevance to axSpA and PsA is an important topic of ongoing research.

Although not found in rheumatoid arthritis synovial fluid, IL-17A-producing conventional CD8+T cells are present in synovial fluid of inflamed joints in patients with AS and PsA where their levels correlate with disease activity. ${ }^{71279}$ IL-17-producing mucosal-associated invariant T (MAIT) cells have been identified in skin and blood from patients with psoriasi ${ }^{80}$ and are also increased in the synovial fluid and blood of patients with AS, where they produce IL-17A in an IL-7-dependent fashion. ${ }^{81} 82$

It has been suggested that neutrophils contribute to the amplification of the inflammatory response in $\mathrm{SpA}$ by producing further IL-17A and although IL-17A-positive neutrophils have been reported in psoriatic skin, the synovium of patients with PsA, and in AS facet joints, ${ }^{83-88}$ the emerging consensus is that neutrophils do not produce IL-17A mRNA or protein, even after strong stimulation with various cytokine combinations. ${ }^{89}$ Similarly, although IL-17A-positive mast cells have been found in synovial tissue from patients with SpA, ${ }^{90}$ the concept is of exogenous IL-17A capture and release, as opposed to synthesis. ${ }^{91}$ A recent study indicated that levels of IL-17A were higher in joint-resident mast cells following IL-17A inhibition, which supports the concept of storage of this cytokine under normal tissue homoeostasis and mast cell release during inflammation. ${ }^{92}$

A key research question for the future will be identifying all IL-17A-producing populations, especially at the enthesis in SpA. It is noteworthy that measurement of serum levels of IL-17A is likely to be of minimal relevance due to the local tissue responses seen in SpA via IL-17A-producing resident cells.

\section{Enthesitis}

Considerable recent developments have occurred in experimental enthesitis research where high mechanical stressing at entheses is associated with local immune system activation. ${ }^{59} 9394$ Non-SpA-related enthesitis can result from repeated mechanical strain in healthy individuals (eg, tennis elbow) and usually resolves spontaneously, whereas inflammation in SpA shows chronicity. ${ }^{59}$ The underlying mechanisms behind this pathologically exaggerated immune response, which is driven by a combination of genetic factors and disturbed epithelial barrier function, are starting to be unravelled. ${ }^{59}$ 95-97

Enthesitis is triggered predominantly by an innate immune response. Prostaglandin E2 (PGE2) and IL-23 may be important early mediators, activating resident immune cells to produce IL-17A and other inflammatory cytokines. Indeed, peri-entheseal bone involvement and the often excellent responses observed with NSAIDs incriminate PGE2 in axial disease. ${ }^{59}$ In mice, hepatic expression of IL-23 induces spondyloarthropathy by acting on ROR- $\gamma t+C D 3+C D 4-C D 8$ - entheseal resident $T$ cells to produce inflammatory mediators including IL-17A. ${ }^{98}$ $\gamma / \delta$ T cells have been shown to constitute the large majority of murine IL-17A producing cells, proliferating at the site of injury, and enhancing bone regeneration. ${ }^{99} 100$ However, although enthesitis appears to be a cardinal lesion in several IL-23/17 axis murine models of inflammatory arthritis, ${ }^{101-107}$ other models have indicated that disease can arise in a T-cell independent manner including that mediated by TNF production from entheseal myeloid and stromal cells. ${ }^{94} 108-110$

In humans, IL-17A-producing enthesis-resident ILC3 and $\gamma \delta \mathrm{T}$ cells have recently been described. ${ }^{56-58}$ Resident myeloid cells that can locally produce IL-23 have also been described, ${ }^{111}$ and their numbers in man may be linked to mechanical load. ${ }^{108}$ IL-17A likely acts as an amplifier of enthesitis, inducing several other cytokines by resident mesenchymal cells. ${ }^{98112113}$ Prolonged entheseal inflammation leads to new bone formation and also, to a much lesser extent, bone erosion, and is subject to considerable research interest. ${ }^{59}$

\section{Bone damage}

Preclinical and clinical data suggest that bone erosion and new bone formation in SpA may occur simultaneously at different anatomical sites, ${ }^{114-117}$ with IL-17A playing a complex role in these processes.

\section{Bone erosion}

Numerous preclinical studies have indicated that IL-17A promotes bone resorption in experimental arthritis. ${ }^{118-121}$ Recent efforts have focused on elucidating the mechanisms behind these effects and indicate that IL-17A stimulates receptor activator of nuclear factor-kB ligand (RANKL) expression and inhibition of Wnt signalling, thereby inhibiting osteoblast activity (figure 3). ${ }^{122-128}$

Clinical data in patients with PsA show a significant reduction in joint radiographic progression with IL-17A inhibitors versus placebo in the short-term and low long-term rates of radiographic progression. ${ }^{13}{ }^{14} 129$ Furthermore, recent data from the PSARTROS study showed no progression of catabolic and anabolic bone changes in the joints of patients with PsA treated with secukinumab for 24 weeks. ${ }^{130}$

\section{New bone formation}

The precise role of IL-17A in new bone formation in axial SpA and PsA is currently unknown, with contradictory experimental findings observed. Studies favouring a role in new bone formation include data from both animal models and human primary cells (summarised in figure 3). IL-17A has been reported to boost osteogenesis via enhancing osteoblast differentiation from local mesenchymal stem cell populations, ${ }^{100}{ }^{131-133}$ and the subsequent 

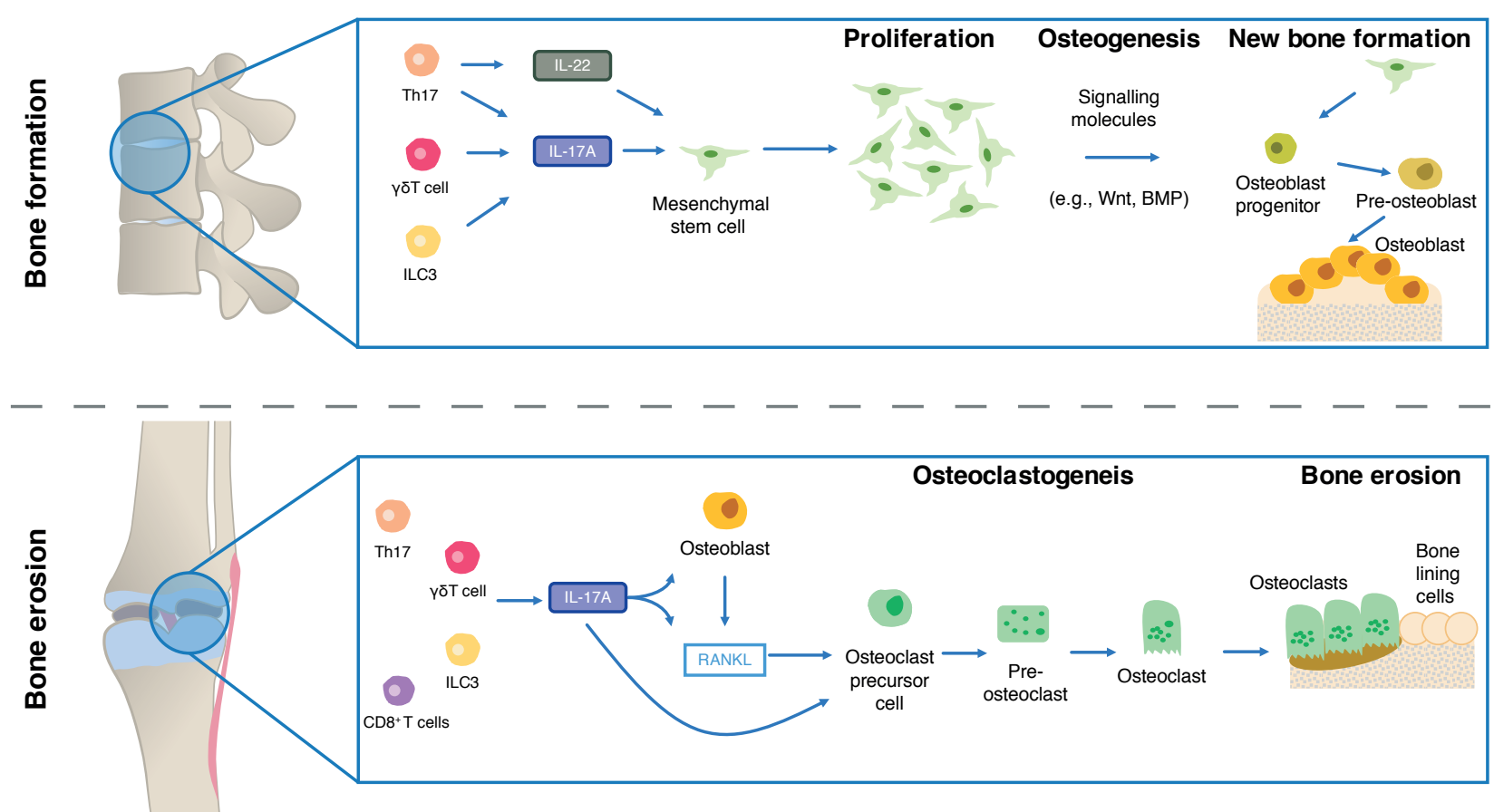

Figure 3 The role of IL-17A in bone erosion and bone formation in spondyloarthritis. Adapted from Schett et al and Gravallese et a/[59 223 231]. BMP, bone morphogenetic protein; ILC3, type 3 innate lymphoid cell; RANKL, receptor activator of nuclear factor kappa-B ligand; Th17, T helper 17 cell.

activation of the osteoblasts via activation of the JAK2/STAT3 signalling pathway, which is associated with osteogenesis. ${ }^{131}$ IL-17A knockout models have been associated with impaired bone regeneration at both 14 and 21 days post a drill-hole fracture in the femur when compared with wild type mice. ${ }^{100}$ Furthermore, in the mycobacterium tuberculosis-induced diseased HLA-B27 transgenic rat model of SpA, IL-17A blockade significantly suppressed pathological new bone formation. ${ }^{134}$ In humans, IL-17A levels are elevated in the days following fracture, which in turn is associated with callus formation. ${ }^{135}$

In contradistinction, cutaneous-restricted overexpression of IL-17A was associated with bone loss in murine models. ${ }^{136}$ Moreover, rat calvarial defects show impaired healing when exposed to IL-17A, combined with significant impairments in osteogenesis in the isolated cells when exposed to IL-17A. ${ }^{137}$ In vivo, IL-17A is associated with osteoclastogenic activation and systemic bone loss in rheumatoid arthritis. ${ }^{122} 124$ Thus, determining the role of IL-17A in new bone formation remains an important avenue of future research.

\section{Pain}

The immune system plays a critical role in modulating acute and chronic pain in both the peripheral and central nervous systems. ${ }^{138} 139$ Although pain in SpA is often assumed to be a surrogate marker for inflammation, evidence is emerging to suggest a more complex picture. In axSpA, pain does not always correlate with inflammation or radiographic measures of disease. ${ }^{140}$ Furthermore, neuropathic pain as well as inflammatory pain has been observed in patients with AS and PsA. ${ }^{141} 142$

IL-17A can modulate inflammatory pain by directly increasing nociceptor excitability and potentiating hyperalgesia through the induction of secondary factors. ${ }^{139}{ }^{143-146}$ Both IL-17RA and IL-17RC are expressed in murine neuronal tissue where they contribute to inflammatory responses. ${ }^{147} 148$ Preclinical studies also suggests a role for IL-17A in neuropathic pain. ${ }^{149-152}$ Clinical data with inhibitors of IL-17A in AS and PsA show rapid and significant pain reduction, ${ }^{153} 154$ but work to assess whether this represents a reduction in neuropathic as well as inflammatory pain is needed.

\section{Gut inflammation in SpA}

The role of IL-17A in IBD and its potential link to the pathogenesis of axSpA and PsA has been the subject of some controversy. Historically, preclinical data investigating the outcome of IL-17A inhibition in mouse IBD models have been inconsistent, with some studies showing disease protection and others showing exacerbation. ${ }^{155156}$ Clinically, IL-17A inhibition was ineffective in moderate-to-severe Crohn's disease. ${ }^{20}$ Long-term clinical trial and postmarketing safety data in psoriasis, PsA and AS indicate that the overall incidence of IBD is low, within the expected range in these disorders, and not exacerbated by secukinumab treatment. ${ }^{157}$ This highlights one of the pitfalls of translating preclinical data to a clinical setting and has led researchers to reconsider the preclinical IBD models. Nevertheless, long-term data with IL-17A inhibitors in clinical practice are required to investigate this issue further.

The $\gamma \delta$ T cell was the principal source of gut-derived IL-17A in a mouse model of colitis, where IL-17A-dependent regulation of the tight junction protein occludin during epithelial injury was shown to maintain barrier integrity. ${ }^{158}$ Mucosal tissues have also emerged as a key physiological site for the differentiation and regulation of Th17 cells. ${ }^{77159} 160$ A role for ILC3 and innate-like $\mathrm{T}$ cells such as iNKT cells and MAIT cells in IBD is also postulated based on their high representation at barrier sites. ${ }^{161-163}$ Putative links have also been suggested between gut inflammation, migration and accumulation of IL-17A-producing ILC3 cells in the joints of patients with AS. ${ }^{164} \mathrm{~A}$ recent study also found that pathogenic bacteria can induce intestinal barrier defects and translocate to systemic organs, triggering autoimmune disease. ${ }^{165}$

\section{Uveitis}

Like IBD, anterior uveitis in SpA shares common genetic risk factors and the involvement of certain pro-inflammatory 
Secukinumab ${ }^{12-16,20,21,168,232-235}$

Psoriasis, PsA, AS

Approved indications

MoA

PsA

Peripheral arthritis

Enthesitis

Dactylitis

Skin

Nail

Axial disease

Structural progression

AS

Signs and symptoms

Disease activity

Function

Structural progression

Non-radiographic axial SpA

Psoriasis

Crohn's disease

Uveitis $^{a}$

\section{Effective}

Under investigation

Fully-human anti-IL-17A antibody

Not effective
Ixekizumab ${ }^{17-19,169,236,237}$

Psoriasis, PsA

Humanised anti-IL-17A antibody
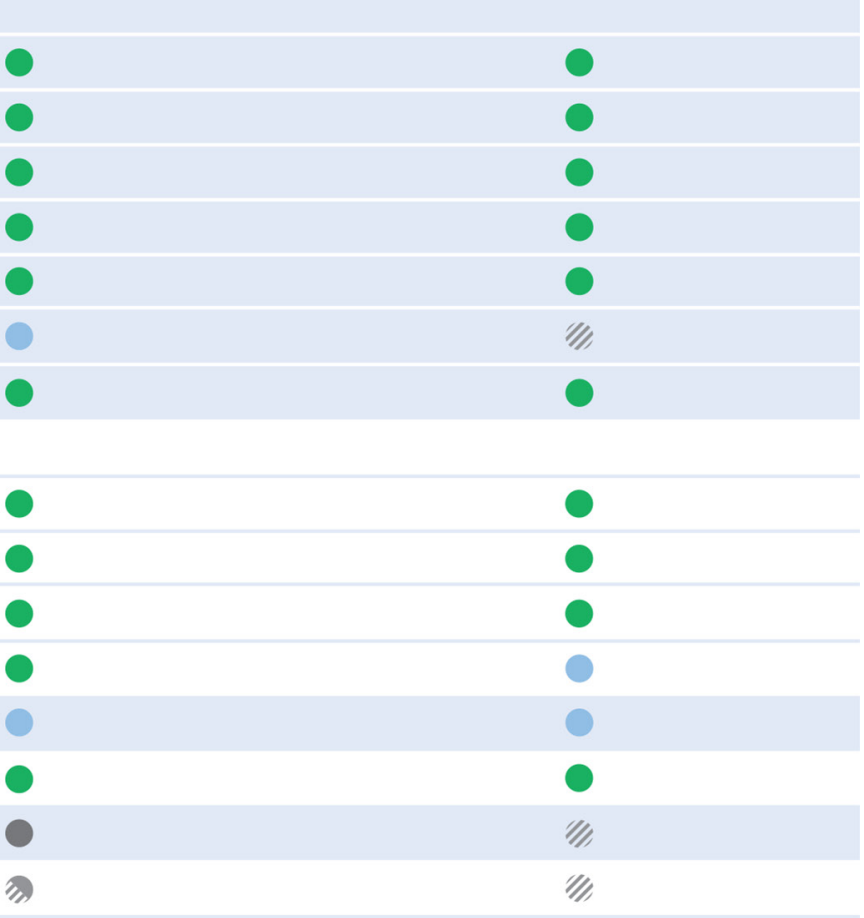

U/, Not assessed

Figure 4 Summary of clinical efficacy with IL-17A inhibitors in spondyloarthritis. ${ }^{a}$ No efficacy shown with secukinumab in non-infectious uveitis; not investigated in anterior uveitis, the form of the disease most common in patients with spondyloarthritis. AS, ankylosing spondylitis; PsA, psoriatic arthritis; SpA, spondyloarthritis.

cytokines. Clinical trials have demonstrated the efficacy of anti-TNF monoclonal antibody therapy in panuveitis or posterior uveitis but clinical trials with inhibitors of IL-17A have failed to meet their primary endpoints for these forms of the disease that are pathophysiologically distinct from anterior uveitis. ${ }^{21}$ Both IL-17A and IL-17F have been detected in anterior uveitis (reviewed in Weinstein and Pepple), but whether they play a critical role is unclear. ${ }^{166}$ In secukinumab-treated AS patients there was no evidence suggesting uveitis flares in patients with previous anterior uveitis. ${ }^{167}$ Further research is required to extend our understanding of the precise role of IL-17A in the pathogenesis of anterior uveitis.

\section{TARGETING IL-17A IN SPA}

The key role played by IL-17A in the pathogenesis of AS and PsA is highlighted by the efficacy shown by inhibitors of IL-17A in clinical trials. Secukinumab, a fully human anti-IL-17A monoclonal antibody, is approved for the treatment of psoriasis, PsA and AS based on the results of several large randomised controlled trials. ${ }^{12-16168}$ Ixekizumab, a humanised anti-IL-17A antibody, is approved for the treatment of psoriasis and PsA and has shown significant efficacy in two large phase III trials in AS. ${ }^{17-19} 169170$ The efficacy of IL-17A inhibitors across all manifestations of disease in AS and PsA, including skin, nails, peripheral arthritis, axial disease, dactylitis and enthesitis, highlights the utility of drugs targeting this pathway (figure 4). Inhibitors of IL-17A have also been shown to have an overall favourable long-term safety profile in clinical trials, ${ }^{32} 3335$ including low rates of serious infections, Candida infections and malignancy, with no evidence of increased suicidality or IBD exacerbation above expected background levels. ${ }^{157}$ Nevertheless, the long-term safety of IL-17A inhibitors will need to be monitored in a real-world setting.

\section{WHAT IS THE BASIS FOR DIVERGENT IL-17A AND IL-23 RESPONSES IN AXIAL DISEASE?}

IL-23 plays a key role in amplifying and maintaining IL-17A production in many cells, so it was expected that IL-23 inhibitor therapy would have similar results to IL-17A inhibition in axSpA. Interestingly, clinical studies with ustekinumab, an IL-12/-23 inhibitor, in axial SpA were terminated due to lack of efficacy ${ }^{171}$ and the IL-23 p19 inhibitor risankizumab also failed to show efficacy in AS in a phase II proof of concept study. ${ }^{172}$ Conversely, the efficacy of IL-17A inhibition in AS suggests that IL-17A and not IL-23 is the major cytokine mediating disease pathogenesis in axSpA and in this context, IL-17A is likely to be produced in a largely IL-23-independent manner. Understanding the reasons for these divergent roles of IL-23 and IL-17A in the pathophysiology of axSpA is one of the hottest topics in current IL-17A research. Emerging evidence suggests there may be anatomical and immunological differences between axial and peripheral enthesitis and subsequent downstream disease manifestations (figure 5). For instance, there is generally more entheseal soft tissue inflammation or synovio-entheseal complex disease in peripheral enthesitis in PsA, ${ }^{173}$ and more peri-entheseal osteitis in the spine in AS, with this bone proclivity being linked to carriage 


\section{A. Anatomic differences between spinal and peripheral entheses}
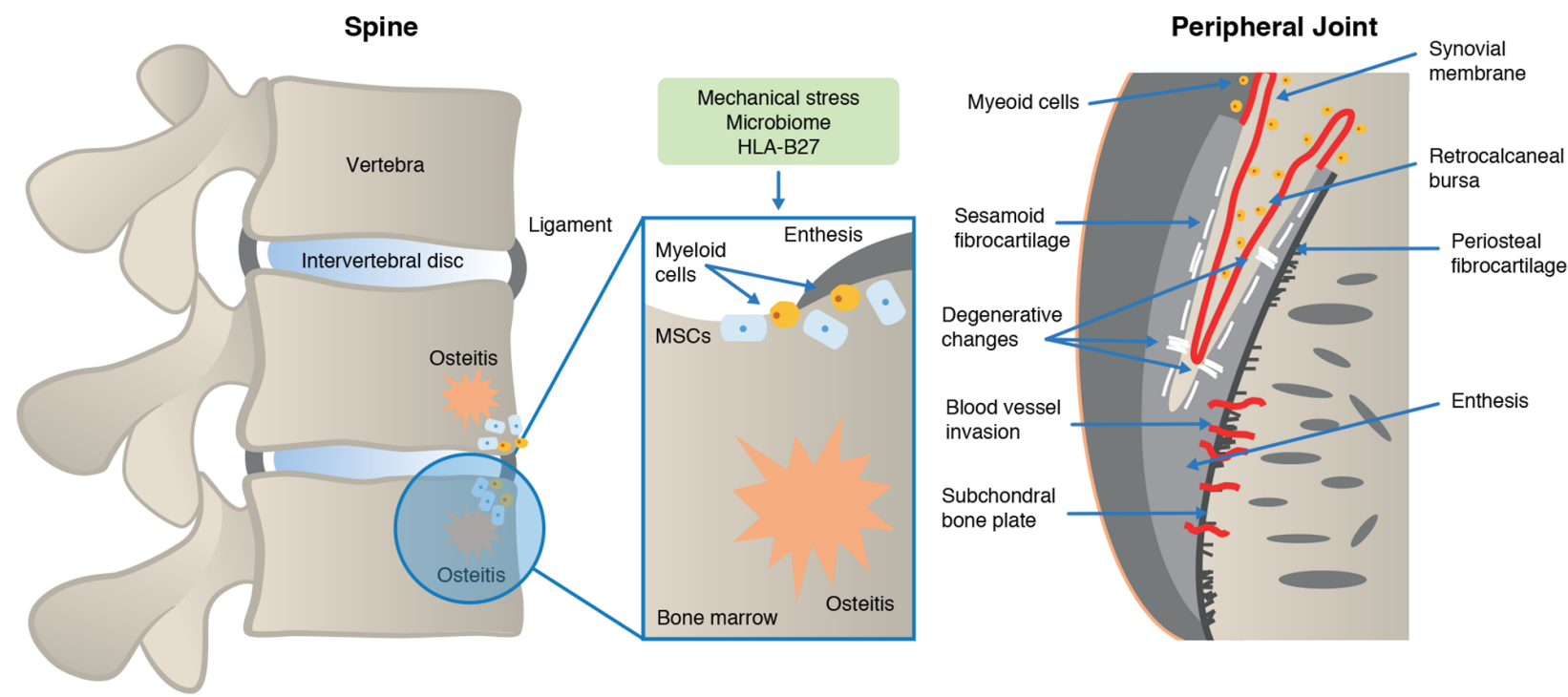

B. Differential cytokine effects in AS, PsA and PsO

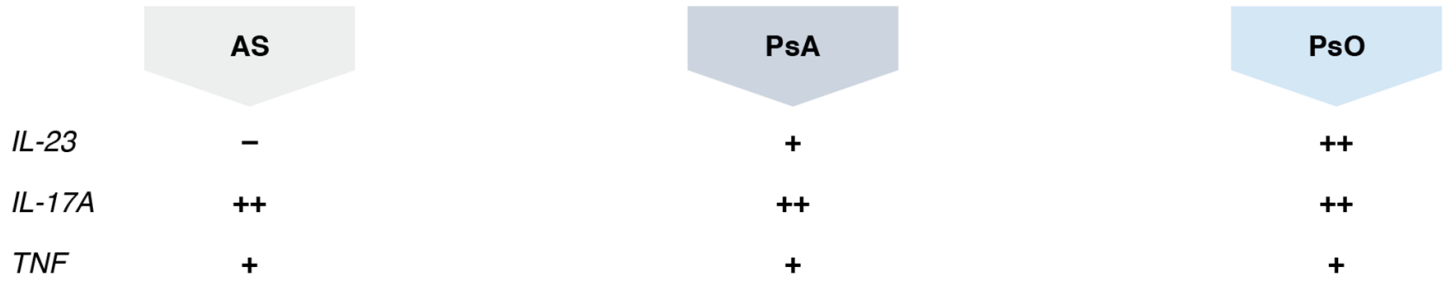

\section{IL-17A production in spinal entheses}

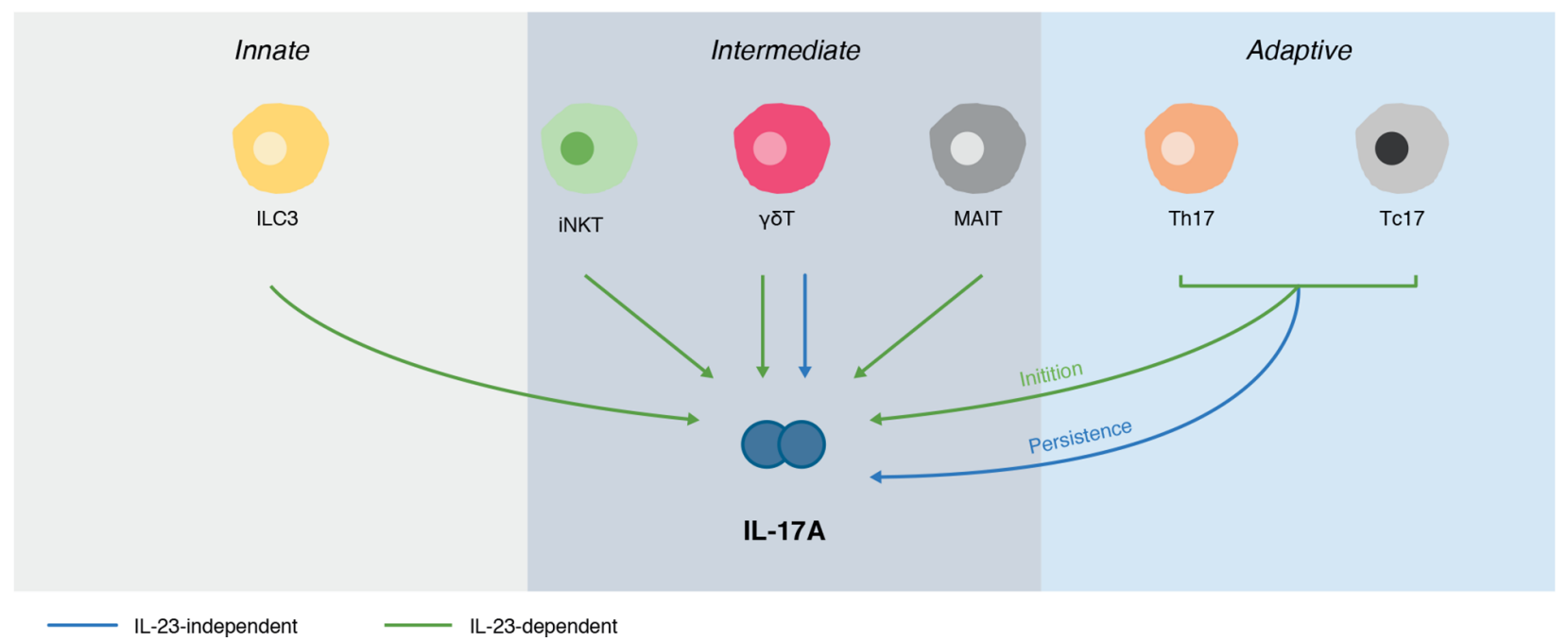

Figure 5 Emergent scheme to explain IL-23/-17 axis pathway divergence in PSA and AS. IL-23 pathway blockade is highly effective in psoriasis but not in AS, which is unexpected given the IL-23 SNPs and related gene SNPs associated with AS. Anatomical differences between entheses in the spine versus peripheral joints could play a role (A). The peripheral skeleton has numerous synovio-entheseal complexes, ${ }^{173}$ which contain abundant myeloid cells, while these cells are rare in the spine. Spinal enthesitis is also associated with peri-entheseal bone disease and osteitis. ${ }^{59173238}$ The role of inflammatory cytokines, namely IL-23, IL-17A and TNF $\alpha$, also differs across the spondyloarthritidies (B). ${ }^{12}$ 14-16 167 168 172 239-248 IL-17A can be produced by several different sources in spinal entheses (C). ${ }^{56-59} 7475818299100158175249$ Emerging evidence supports the cellular basis for IL-17 production that is independent of IL-23. ${ }^{5657158} 175$ Animal models also show that IL-23 has a redundant role once adaptive immunity is primed. ${ }^{175}$ Where ++ , strong involvement; +, involvement; -, no involvement. AS, ankylosing spondylitis; $\gamma \delta \mathrm{T}$, gamma delta T cells; HLA-B27, human leucocyte antigen B27; IL-17A, interleukin 17A; IL-23, interleukin 23; ILC3, Type three innate lymphoid cells; iNKT, innate natural killer T cell; MAIT, mucosal associated invariant T cell; MSCs, mesenchymal stem cells; PsA, psoriatic arthritis; Ps0, psoriasis; Tc17, CD8+T cells; Th17, T helper 17 cells; TNF, tumour necrosis factor $\alpha$. 
of the HLA-B27 gene for axial disease. ${ }^{174}$ In terms of control of IL-17 production, IL-23 receptor positive and negative subpopulations of $\gamma \delta \mathrm{T}$ cells have been identified in human spinous processes entheses, pointing to a role for IL-23-independent IL-17A production, ${ }^{57}$ and enthesis-resident myeloid cells are capable of IL-23 production locally. ${ }^{111}$ Further research is required to investigate the drivers of this process in the future although data in mice indicate that the initiation, but not the persistence, of experimental SpA is dependent on IL-23. ${ }^{175}$

\section{CONCLUSION}

The IL-17A inhibitors show efficacy in treating multiple facets of $\mathrm{SpA}$, including psoriasis, enthesitis, synovitis, bone erosion, new bone formation and pain, which illustrates the importance of IL-17A in disease pathophysiology. Future research will investigate key remaining gaps, such as the role of human enthesis-resident innate and adaptive $\mathrm{T}$ cells in SpA and our understanding of IL-23-independent IL-17A production. The ongoing assessment of IL-17A inhibitors in a real-world setting will also be important as these agents become more widely prescribed in clinical practice. Ongoing research efforts will attempt to answer these and other open questions and shed further light on the role of IL-17A in SpA in the hope of furthering our understanding and improving treatment of these diseases.

Correction notice This article has been corrected since it published Online First. The last sentence in the second paragraph of the 'Well-defined role of IL-17A in host defence' section has been updated for clarity.

Acknowledgements The authors would like to acknowledge the following individuals for their help in the preparation of this work: Darren Asquith and Lindsey Hanson from Novartis UK.

Contributors All authors provided a substantial contribution to the conception, design and interpretation of the work, drafted the work or revised it critically for important intellectual content, and provided final approval of the submitted version of the manuscript.

Funding Medical writing support was provided by Ben Drever from Seren Communications, an Ashfield Company, part of UDG Healthcare, the funding for which was provided by Novartis.

Competing interests RM reports grants and personal fees from Novartis, during the conduct of the study. DGM reports grant and personal fees from Novartis, outside the submitted work. IBM reports personal fees from AbbVie, grants and personal fees from BMS, personal fees from Celgene, grants and personal fees from Janssen, personal fees from Lilly, personal fees from Novartis, grants and personal fees from UCB, personal fees from Leo, grants from Astra Zeneca, grants from Boehringer Ingelheim, outside the submitted work; BWK reports grants and personal fees from AbbVie, grants and personal fees from Eli Lilly \& Co, grants and personal fees from Novartis, grants from Roche, grants from UCB, personal fees from Janssen, personal fees from Pfizer, personal fees from Sandoz, outside the submitted work. JS reports personal fees from AbbVie, personal fees from BMS, personal fees from Celgene, personal fees from Janssen, personal fees from Novartis, personal fees from UCB, personal fees from Merck, outside the submitted work.

Patient consent for publication Not required.

Provenance and peer review Not commissioned; externally peer reviewed.

Open access This is an open access article distributed in accordance with the Creative Commons Attribution Non Commercial (CC BY-NC 4.0) license, which permits others to distribute, remix, adapt, build upon this work non-commercially, and license their derivative works on different terms, provided the original work is properly cited, appropriate credit is given, any changes made indicated, and the use is non-commercial. See: http://creativecommons.org/licenses/by-nc/4.0/.

\section{REFERENCES}

1 Wright V. Seronegative polyarthritis: a unified concept. Arthritis Rheum 1978;21:619-33

2 Rudwaleit M, Khan MA, Sieper J. The challenge of diagnosis and classification in early ankylosing spondylitis: do we need new criteria? Arthritis Rheum 2005;52:1000-8
3 van der Heijde D, Ramiro S, Landewe R, et al. Update of the ASAS-EULAR management recommendations for axial spondyloarthritis. Ann Rheum Dis 2016;2017:978-91.

4 McGonagle D, McDermott MF. A proposed classification of the immunological diseases. PLoS Med 2006;3:e297.

5 Lande R, Botti E, Jandus C, et al. The antimicrobial peptide LL37 is a T-cell autoantigen in psoriasis. Nat Commun 2014;5.

6 Mease PJ, Armstrong AW. Managing patients with psoriatic disease: the diagnosis and pharmacologic treatment of psoriatic arthritis in patients with psoriasis. Drugs 2014;74:423-41.

7 Jadon DR, Sengupta R, Nightingale A, et al. Axial disease in psoriatic arthritis study: defining the clinical and radiographic phenotype of psoriatic spondyloarthritis. Ann Rheum Dis 2017:76:701-7.

8 Brewerton DA, Nicholls A, Caffrey M, et al. HL-A 27 and arthropathies associated with ulcerative colitis and psoriasis. The Lancet 1974;303:956-8.

9 Brown MA, Pile KD, Kennedy LG, et al. HLA class I associations of ankylosing spondylitis in the white population in the United Kingdom. Ann Rheum Dis 1996;55:268-70.

10 Winchester R, Minevich G, Steshenko V, et al. HLA associations reveal genetic heterogeneity in psoriatic arthritis and in the psoriasis phenotype. Arthritis Rheum 2012;64:1134-44

11 Taams LS, Steel KJA, Srenathan U, et al. IL-17 in the immunopathogenesis of spondyloarthritis. Nat Rev Rheumatol 2018;14:453-66.

12 Langley RG, Elewski BE, Lebwohl M, et al. Secukinumab in plaque psoriasis--results of two phase 3 trials. N Engl J Med 2014;371:326-38.

13 Mease $P$, van der Heijde $D$, Landewé $R$, et al. Secukinumab improves active psoriatic arthritis symptoms and inhibits radiographic progression: primary results from the randomised, double-blind, phase III future 5 study. Ann Rheum Dis 2018;77:890-7.

14 Mease PJ, Mclnnes IB, Kirkham B, et al. Secukinumab inhibition of interleukin-17A in patients with psoriatic arthritis. N Eng/ J Med 2015;373:1329-39.

15 McInnes IB, Mease PJ, Kirkham B, et al. Secukinumab, a human anti-interleukin-17A monoclonal antibody, in patients with psoriatic arthritis (future 2): a randomised, double-blind, placebo-controlled, phase 3 trial. The Lancet 2015;386:1137-46.

16 Baeten D, Sieper J, Braun J, et al. Secukinumab, an interleukin-17A inhibitor, in ankylosing spondylitis. N Eng/ J Med 2015;373:2534-48.

17 Gordon KB, Blauvelt A, Papp KA, et al. Phase 3 trials of ixekizumab in moderate-tosevere plaque psoriasis. N Engl J Med 2016;375:345-56.

18 Nash P, Kirkham B, Okada M, et al. Ixekizumab for the treatment of patients with active psoriatic arthritis and an inadequate response to tumour necrosis factor inhibitors: results from the 24-week randomised, double-blind, placebo-controlled period of the SPIRIT-P2 phase 3 trial. The Lancet 2017;389:2317-27.

19 Mease PJ, van der Heijde D, Ritchlin CT, et al. Ixekizumab, an interleukin-17A specific monoclonal antibody, for the treatment of biologic-naive patients with active psoriatic arthritis: results from the 24-week randomised, double-blind, placebocontrolled and active (adalimumab)-controlled period of the phase III trial SPIRIT-P1. Ann Rheum Dis 2017;76:79-87.

20 Hueber W, Sands BE, Lewitzky S, et al. Secukinumab, a human anti-IL-17A monoclonal antibody, for moderate to severe Crohn's disease: unexpected results of a randomised, double-blind placebo-controlled trial. Gut 2012;61:1693-700.

21 Dick AD, Tugal-Tutkun I, Foster S, et al. Secukinumab in the treatment of noninfectious uveitis: results of three randomized, controlled clinical trials. Ophthalmology 2013;120:777-87.

22 Sharma SM, Fu DJ, Xue K. A review of the landscape of targeted immunomodulatory therapies for non-infectious uveitis. Ophthalmol Ther 2018;7:1-17.

23 Gaffen SL. Structure and signalling in the IL-17 receptor family. Nat Rev Immunol 2009:9:556-67.

24 Amatya N, Garg AV, Gaffen SL. IL-17 signaling: the yin and the Yang. Trends Immunol 2017:38:310-22.

25 Ishigame H, Kakuta S, Nagai T, et al. Differential roles of interleukin-17A and -17F in host defense against mucoepithelial bacterial infection and allergic responses. Immunity 2009;30:108-19.

26 Cho JS, Pietras EM, Garcia NC, et al. IL-17 is essential for host defense against cutaneous Staphylococcus aureus infection in mice. I Clin Invest 2010;120:1762-73.

27 Aujla SJ, Dubin PJ, Kolls JK. Th17 cells and mucosal host defense. Semin Immunol 2007:19:377-82.

28 Matsuzaki G, Umemura M. Interleukin-17 family cytokines in protective immunity against infections: role of hematopoietic cell-derived and non-hematopoietic cellderived interleukin-17s. Microbiology and Immunology 2018;62:1-13.

29 Lories RJ, Haroon N. Evolving concepts of new bone formation in axial spondyloarthritis: insights from animal models and human studies. Best Practice \& Research Clinical Rheumatology 2017;31:877-86.

30 Okada S, Puel A, Casanova J-L, et al. Chronic mucocutaneous candidiasis disease associated with inborn errors of IL-17 immunity. Clin Transl Immunology 2016:5:e114.

31 Puel A, Cypowyj S, Maródi L, et al. Inborn errors of human IL-17 immunity underlie chronic mucocutaneous candidiasis. Curr Opin Allergy Clin Immunol 2012;12:616-22. 
32 Mease PJ, McInnes IB, Reich K, et al. Secukinumab demonstrates a consistent safety profile with up to 5 years treatment in patients with psoriatic arthritis and moderate to severe plaque psoriasis: updated pooled safety analyses (Abstract THU0325). Ann Rheum Dis 2018;77:381-2.

33 Deodhar A, Baraliakos X, Marzo-Ortega H, et al. Secukinumab demonstrates consistent safety over long-term exposure (up to 3 years) in patients with active ankylosing spondylitis: pooled analysis of three phase 3 trials. Arthritis Rheumatol 2017;69.

34 Kammüller M, Tsai T-F, Griffiths CEM, et al. Inhibition of IL-17A by secukinumab shows no evidence of increased Mycobacterium tuberculosis infections. Clin Trans/ Immunology 2017;6:e152.

35 Deodhar A, Mease PJ, Mclnnes IB, et al. Long-term safety of secukinumab in patients with moderate-to-severe plaque psoriasis, psoriatic arthritis, and ankylosing spondylitis: integrated pooled clinical trial and post-marketing surveillance data. Arthritis Res Ther 2019;21.

36 Brown MA, Kenna T, Wordsworth BP. Genetics of ankylosing spondylitis--insights into pathogenesis. Nat Rev Rheumatol 2016;12:81-91.

37 Bowness P, Ridley A, Shaw J, et al. Th17 cells expressing KIR3DL2+ and responsive to HLA-B27 homodimers are increased in ankylosing spondylitis. J Immunol 2011:186:2672-80

38 Allen RL, O'Callaghan CA, McMichael AJ, et al. Cutting edge: HLA-B27 can form a novel beta 2-microglobulin-free heavy chain homodimer structure. J Immunol 1999:162:5045-8.

39 DeLay ML, Turner MJ, Klenk El, et al. HLA-B27 misfolding and the unfolded protein response augment interleukin-23 production and are associated with Th17 activation in transgenic rats. Arthritis Rheum 2009;60:2633-43.

40 Colbert RA, DeLay ML, Klenk El, et al. From HLA-B27 to spondyloarthritis: a journey through the ER. Immunol Rev 2010;233:181-202.

41 Burton PR, Clayton DG, Cardon LR, et al. Association scan of 14,500 nonsynonymous SNPs in four diseases identifies autoimmunity variants. Nat Genet 2007:39:1329-37.

42 Evans DM, Spencer CCA, Pointon JJ, et al. Interaction between ERAP1 and HLA-B27 in ankylosing spondylitis implicates peptide handling in the mechanism for HLA-B27 in disease susceptibility. Nat Genet 2011;43:761-7.

43 Tsoi LC, Spain SL, Knight J, et al. Identification of 15 new psoriasis susceptibility loci highlights the role of innate immunity. Nat Genet 2012;44:1341-8.

44 Cortes A, Hadler J, Pointon JP, et al. Identification of multiple risk variants for ankylosing spondylitis through high-density genotyping of immune-related loci. Nat Genet 2013;45:730-8.

45 Filer C, Ho P, Smith RL, et al. Investigation of association of the IL12B and IL23R genes with psoriatic arthritis. Arthritis Rheum 2008;58:3705-9.

46 Bowes J, Orozco G, Flynn E, et al. Confirmation of TNIP1 and II23a as susceptibility loci for psoriatic arthritis. Ann Rheum Dis 2011;70:1641-4.

47 Jostins L, Ripke S, Weersma RK, et al. Host-microbe interactions have shaped the genetic architecture of inflammatory bowel disease. Nature 2012;491:119-24

48 Coffre M, Roumier M, Rybczynska M, et al. Combinatorial control of Th17 and Th1 cell functions by genetic variations in genes associated with the interleukin-23 signaling pathway in spondyloarthritis. Arthritis Rheum 2013:65:1510-21

49 de Beaucoudrey L, Puel A, Filipe-Santos 0, et al. Mutations in STAT3 and IL12RB1 impair the development of human IL-17-producing T cells. J Exp Med 2008;205:1543-50.

50 Danoy P, Pryce K, Hadler J, et al. Association of variants at $1 \mathrm{q} 32$ and STAT3 with ankylosing spondylitis suggests genetic overlap with Crohn's disease. PLoS Genet 2010;6:e1001195.

51 Davidson SI, Liu Y, Danoy PA, et al. Association of STAT3 and TNFRSF1A with ankylosing spondylitis in Han Chinese. Ann Rheum Dis 2011;70:289-92

52 Cénit MC, Ortego-Centeno N, Raya E, et al. Influence of the STAT3 genetic variants in the susceptibility to psoriatic arthritis and Behcet's disease. Hum Immunol 2013;74:230-3.

53 Harris TJ, Grosso JF, Yen H-R, et al. Cutting edge: an in vivo requirement for STAT3 signaling in Th17 development and TH17-dependent autoimmunity. The Journal of Immunology 2007;179:4313-7.

54 Soare A, Weber S, Maul L, et al. Cutting edge: homeostasis of innate lymphoid cells is imbalanced in psoriatic arthritis. J.i. 2018;200:1249-54.

55 Leijten EFA, van Kempen TS, Boes M, et al. Brief report: enrichment of activated group 3 innate lymphoid cells in psoriatic arthritis synovial fluid. Arthritis Rheumatol 2015:67:2673-8

56 Cuthbert R, Fragkakis E, Dunsmuir R, et al. FRI0427 first description of gamma delta T cells at normal human enthesis. Ann Rheum Dis 2017;76:648.

57 Cuthbert R, Fragkakis EM, Bridgewood C, et al. The V $\delta 2$ subset of $\Gamma \delta$ t-cells are present at healthy human enthesis and have transcriptional and functional characteristics consistent with a capacity for IL- 17A production in response to IL-23. Arthritis Rheumatol 1833;2018

58 Cuthbert RJ, Fragkakis EM, Dunsmuir R, et al. Brief report: group 3 innate lymphoid cells in human Enthesis. Arthritis \& Rheumatology 2017;69:1816-22.
59 Schett G, Lories RJ, D’Agostino M-A, et al. Enthesitis: From pathophysiology to treatment. Nat Rev Rheumatol 2017:13:731-41.

60 Venken K, Jacques P, Mortier C, et al. ROR yt inhibition selectively targets IL-17 producing iNKT and $\gamma \delta$-T cells enriched in spondyloarthritis patients. Nat Commun 2019;10.

61 Zhao M, Svensson MND, Venken K, et al. Altered thymic differentiation and modulation of arthritis by invariant NKT cells expressing mutant ZAP70. Nat Commun 2018:9.

62 Park CO, Kupper TS. The emerging role of resident memory T cells in protective immunity and inflammatory disease. Nat Med 2015;21:688-97.

63 Clark RA. Resident memory T cells in human health and disease. Sci Trans/ Med 2015;7:269rv1-1.

64 Cheuk S, Schlums H, Gallais Sérézal I, et al. CD49a Expression Defines TissueResident CD8 ${ }^{+} \mathrm{T}$ Cells Poised for Cytotoxic Function in Human Skin. Immunity 2017:46:287-300.

65 Kirkham BM, Menon B, Taams LS. Immunological and clinical relationships of synovial IL-17+ T cells in psoriatic arthritis. ACR/ARHP Annual Meeting $2014 ; 633$

66 Gaston JSH, Jadon DR. Th17 cell responses in spondyloarthritis. Best Pract Res Clin Rheumatol 2017;31:777-96

67 Lynde CW, Poulin Y, Vender R, et al. Interleukin 17A: toward a new understanding of psoriasis pathogenesis. J Am Acad Dermatol 2014;71:141-50

68 Coimbra S, Figueiredo A, Castro E, et al. The roles of cells and cytokines in the pathogenesis of psoriasis. Int J Dermatol 2012;51:389-98. quiz 95-8.

69 Coimbra S, Oliveira H, Reis F, et al. Interleukin (IL)-22, IL-17, IL-23, IL-8, vascular endothelial growth factor and tumour necrosis factor- $\alpha$ levels in patients with psoriasis before, during and after psoralen-ultraviolet $A$ and narrowband ultraviolet B therapy. Br J Dermatol 2010;163:1282-90.

70 Lowes MA, Kikuchi T, Fuentes-Duculan J, et al. Psoriasis vulgaris lesions contain Discrete populations of Th1 and Th17 T cells. J Invest Dermatol 2008;128:1207-11

71 Menon B, Gullick NJ, Walter GJ, et al. Interleukin-17+CD8+ T cells are enriched in the joints of patients with psoriatic arthritis and correlate with disease activity and joint damage progression. Arthritis Rheumatol 2014;66:1272-81.

72 Jandus C, Bioley G, Rivals J-P, et al. Increased numbers of circulating polyfunctional Th17 memory cells in patients with seronegative spondylarthritides. Arthritis Rheum 2008:58:2307-17.

73 Shen H, Goodall JC, Hill Gaston JS. Frequency and phenotype of peripheral blood Th17 cells in ankylosing spondylitis and rheumatoid arthritis. Arthritis Rheum 2009;60:1647-56

74 Shen H, Goodall JC, Gaston JSH. Frequency and phenotype of Thelper 17 cells in peripheral blood and synovial fluid of patients with reactive arthritis. J Rheumatol 2010;37:2096-9.

75 Al-Mossawi MH, Chen L, Fang $\mathrm{H}$, et al. Unique transcriptome signatures and GMCSF expression in lymphocytes from patients with spondyloarthritis. Nat Commun 2017;8.

76 Benedetti G, Miossec P. Interleukin 17 contributes to the chronicity of inflammatory diseases such as rheumatoid arthritis. Eur J Immunol 2014:44:339-47.

77 Burkett PR, Meyer zu Horste G, Kuchroo VK. Pouring fuel on the fire: Th17 cells, the environment, and autoimmunity. J Clin Invest 2015;125:2211-9.

78 Lee YK, Mukasa R, Hatton RD, et al. Developmental plasticity of Th17 and Treg cells. Curr Opin Immunol 2009;21:274-80.

79 Wang C, Liao Q, Hu Y, et al. T lymphocyte subset imbalances in patients contribute to ankylosing spondylitis. Exp Ther Med 2015;9:250-6.

80 Teunissen MBM, Yeremenko NG, Baeten DLP, et al. The IL-17A-producing CD8+ T-cell population in psoriatic lesional skin comprises mucosa-associated invariant $T$ cells and conventional T cells. J Invest Dermatol 2014;134:2898-907.

81 Gracey E, Qaiyum Z, Almaghlouth I, et al. IL-7 primes IL-17 in mucosal-associated invariant T (MAIT) cells, which contribute to the Th17-axis in ankylosing spondylitis. Ann Rheum Dis 2016;75:2124-32.

82 Hayashi E, Chiba A, Tada K, et al. Involvement of mucosal-associated invariant T cells in ankylosing spondylitis. J Rheumato/ 2016;43:1695-703.

83 Res PCM, Piskin G, de Boer OJ, et al. Overrepresentation of IL-17A and IL-22 producing CD8 T cells in lesional skin suggests their involvement in the pathogenesis of psoriasis. PLoS One 2010;5:e14108.

$84 \mathrm{Kim}$ J, Krueger JG. The immunopathogenesis of psoriasis. Dermato/ Clin 2015;33:13-23.

85 Korn T, Bettelli E, Oukka M, et al. IL-17 and Th17 cells. Annu Rev Immunol 2009;27:485-517

86 Keiisers RRMC, Joosten I, van Erp PEJ, et al. Cellular sources of IL-17 in psoriasis: a paradigm shift? Exp Dermatol 2014;23:799-803.

87 Moran EM, Heydrich R, Ng CT, et al. IL-17A expression is localised to both mononuclear and polymorphonuclear synovial cell infiltrates. PLoS One 2011:6:e24048.

88 Appel H, Maier R, Wu P, et al. Analysis of IL-17(+) cells in facet joints of patients with spondyloarthritis suggests that the innate immune pathway might be of greater relevance than the Th17-mediated adaptive immune response. Arthritis Res Ther 2011;13. 
89 Tamassia N, Arruda-Silva F, Calzetti F, et al. A Reappraisal on the Potential Ability of Human Neutrophils to Express and Produce IL-17 Family Members In Vitro: Failure to Reproducibly Detect It. Front Immunol 2018;9.

90 Noordenbos T, Yeremenko N, Gofita I, et al. Interleukin-17-positive mast cells contribute to synovial inflammation in spondylarthritis. Arthritis Rheum 2012;64:99-109.

91 Noordenbos T, Blijdorp I, Chen S, et al. Human mast cells capture, store, and release Bioactive, exogenous IL-17A. J Leukoc Biol 2016;100:453-62.

92 Chen S, Noordenbos T, Blijdorp I, et al. Histologic evidence that mast cells contribute to local tissue inflammation in peripheral spondyloarthritis by regulating interleukin17A content. Rheumatology 2019;58:617-27.

93 McGonagle D, Gibbon W, Emery P. Classification of inflammatory arthritis by enthesitis. The Lancet 1998;352:1137-40.

94 Cambré I, Gaublomme D, Schryvers N, et al. Running promotes chronicity of arthritis by local modulation of complement activators and impairing $T$ regulatory feedback loops. Ann Rheum Dis 2019;78:787-95.

95 Reveille JD. Genetics of spondyloarthritis--beyond the MHC. Nat Rev Rheumatol 2012;8:296-304

96 McGonagle D, Tan AL. The enthesis in psoriatic arthritis. Clin Exp Rheumatol 2015;33(5 Suppl 93):S36-9.

97 Xavier RJ, Podolsky DK. Unravelling the pathogenesis of inflammatory bowel disease. Nature 2007:448:427-34.

98 Sherlock JP, Joyce-Shaikh B, Turner SP, et al. IL-23 induces spondyloarthropathy by acting on ROR- $\gamma t+C D 3+C D 4-C D 8$ - entheseal resident T cells. Nat Med 2012;18:1069-76.

99 Reinhardt A, Yevsa T, Worbs T, et al. Interleukin-23-Dependent $\gamma / \delta$ T cells produce interleukin-17 and accumulate in the Enthesis, aortic valve, and ciliary body in mice. Arthritis Rheumatol 2016:68:2476-86.

100 Ono T, Okamoto K, Nakashima T, et al. IL-17-producing $\gamma \delta$ T cells enhance bone regeneration. Nat Commun 2016;7.

101 Benham H, Rehaume LM, Hasnain SZ, et al. Interleukin-23 mediates the intestinal response to microbial $\beta$-1,3-glucan and the development of spondyloarthritis pathology in SKG mice. Arthritis Rheumatol 2014;66:1755-67.

102 Ruutu M, Thomas G, Steck R, et al. $\beta$-glucan triggers spondylarthritis and Crohn's disease-like ileitis in SKG mice. Arthritis Rheum 2012;64:2211-22.

103 Braem K, Carter S, Lories RJ. Spontaneous arthritis and ankylosis in male DBA/1 mice: further evidence for a role of behavioral factors in "stress-induced arthritis". Biol Proced Online 2012;14.

104 Ebihara S, Date F, Dong Y, et al. Interleukin-17 is a critical target for the treatment of ankylosing enthesitis and psoriasis-like dermatitis in mice. Autoimmunity 2015:48:259-66.

105 Rehaume LM, Mondot S, Aguirre de Cárcer D, et al. ZAP-70 genotype disrupts the relationship between microbiota and host, leading to spondyloarthritis and ileitis in SKG mice. Arthritis Rheumatol 2014;66:2780-92.

106 Khmaladze I, Kelkka T, Guerard S, et al. Mannan induces ROS-regulated, IL-17Adependent psoriasis arthritis-like disease in mice. Proceedings of the National Academy of Sciences 2014;111:E3669-E3678.

107 Yamamoto M, Nakajima K, Takaishi M, et al. Psoriatic inflammation facilitates the onset of arthritis in a mouse model. J Invest Dermatol 2015;135:445-53.

108 Cambré I, Gaublomme D, Burssens A, et al. Mechanical strain determines the sitespecific localization of inflammation and tissue damage in arthritis. Nat Commun 2018;9.

109 De Wilde K, Martens A, Lambrecht S, et al. A20 inhibition of STAT1 expression in myeloid cells: a novel endogenous regulatory mechanism preventing development of enthesitis. Ann Rheum Dis 2017:76:585-92.

110 Jacques $P$, Lambrecht $S$, Verheugen $E$, et al. Proof of concept: enthesitis and new bone formation in spondyloarthritis are driven by mechanical strain and stromal cells. Ann Rheum Dis 2014;73:437-45.

111 Bridgewood C, Watad A, Russell T, et al. Identification of myeloid cells in the human enthesis as the main source of local IL-23 production. Ann Rheum Dis 2019;78:929-33.

112 Yu JJ, Ruddy MJ, Wong GC, et al. An essential role for IL-17 in preventing pathogeninitiated bone destruction: recruitment of neutrophils to inflamed bone requires IL-17 receptor-dependent signals. Blood 2007;109:3794-802.

113 Ye P, Rodriguez FH, Kanaly S, et al. Requirement of interleukin 17 receptor signaling for lung $\mathrm{CXC}$ chemokine and granulocyte colony-stimulating factor expression, neutrophil recruitment, and host defense. J Exp Med 2001;194:519-28.

114 Lories RJU, Luyten FP, de Vlam K. Progress in spondylarthritis. Mechanisms of new bone formation in spondyloarthritis. Arthritis Res Ther 2009;11.

115 McGonagle D, Wakefield RJ, Tan AL, et al. Distinct topography of erosion and new bone formation in Achilles tendon enthesitis: implications for understanding the link between inflammation and bone formation in spondylarthritis. Arthritis Rheum 2008:58:2694-9.

116 van Duivenvoorde LM, Dorris ML, Satumtira N, et al. Relationship between inflammation, bone destruction, and osteoproliferation in the HLA-B27/human $\beta 2$-microglobulin-transgenic rat model of spondylarthritis. Arthritis Rheum 2012;64:3210-9
117 Dibra D, Xia X, Gagea M, et al. A spontaneous model of spondyloarthropathies that develops bone loss and pathological bone formation: a process regulated by IL27RA-/- and mutant-p53. PLoS One 2018;13:e0193485.

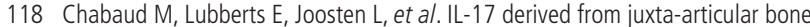
and synovium contributes to joint degradation in rheumatoid arthritis. Arthritis Res 2001;3:168-77.

119 Chabaud M, Miossec P. The combination of tumor necrosis factor ? blockade with interleukin-1 and interleukin-17 blockade is more effective for controlling synovial inflammation and bone resorption in an ex vivo model. Arthritis \& Rheumatism 2001;44:1293-303.

120 Lubberts E, van den Bersselaar L, Oppers-Walgreen B, et al. IL-17 promotes bone erosion in murine collagen-induced arthritis through loss of the receptor activator of NF-kappa B ligand/osteoprotegerin balance. J Immunol 2003;170:2655-62.

121 Adamopoulos IE, Chao C-chi, Geissler R, et al. Interleukin-17A upregulates receptor activator of NF-кB on osteoclast precursors. Arthritis Research \& Therapy 2010;12.

122 Sato K, Suematsu A, Okamoto K, et al. Th17 functions as an osteoclastogenic helper T cell subset that links T cell activation and bone destruction. J Exp Med 2006;203:2673-82.

123 Iwakura Y, Nakae S, Saijo S, et al. The roles of IL-17A in inflammatory immune responses and host defense against pathogens. Immunol Rev 2008;226:57-79.

124 Kotake S, Udagawa N, Takahashi N, et al. IL-17 in synovial fluids from patients with rheumatoid arthritis is a potent stimulator of osteoclastogenesis. J. Clin. Invest. 1999; 103:1345-52.

125 Ke D, Fu X, Xue Y, et al. IL-17A regulates the autophagic activity of osteoclast precursors through RANKL-JNK1 signaling during osteoclastogenesis in vitro. Biochem Biophys Res Commun 2018;497:890-6.

126 Yang L, Fanok MH, Mediero-Munoz A, et al. Augmented Th17 differentiation leads to cutaneous and Synovio-Entheseal inflammation in a novel model of psoriatic arthritis. Arthritis Rheumatol 2018;70:855-67.

127 Wang Z, Jia Y, Du F, et al. IL-17A inhibits osteogenic differentiation of bone mesenchymal stem cells via Wnt signaling pathway. Med Sci Monit 2017; 23:4095-101.

128 Zhang J-R, Pang D-D, Tong Q, et al. Different modulatory effects of IL-17, IL-22, and IL-23 on osteoblast differentiation. Mediators of Inflammation 2017;2017:1-11.

129 Mease PJ, Kavanaugh A, Reimold A, et al. Secukinumab in the treatment of psoriatic arthritis: efficacy and safety results through 3 years from the year 1 extension of the randomised phase III future 1 trial. RMD Open 2018:4:e000723.

130 Kampylafka E, d'Oliveira I, Linz C, et al. Resolution of synovitis and arrest of catabolic and anabolic bone changes in patients with psoriatic arthritis by IL-17A blockade with secukinumab: results from the prospective PSARTROS study. Arthritis Res Ther 2018:20.

131 Jo S, Wang SE, Lee YL, et al. IL-17A induces osteoblast differentiation by activating JAK2/STAT3 in ankylosing spondylitis. Arthritis Res Ther 2018;20.

132 Jo S, Lee JK, Han J, et al. Identification and characterization of human bone-derived cells. Biochem Biophys Res Commun 2018;495:1257-63.

133 Croes M, Öner FC, van Neerven D, et al. Proinflammatory T cells and IL-17 stimulate osteoblast differentiation. Bone 2016;84:262-70.

134 van Tok MN, van Duivenvoorde LM, Kramer I, et al. Interleukin-17A inhibition diminishes inflammation and new bone formation in experimental spondyloarthritis. Arthritis Rheumatol 2019:71:612-25.

135 Ono T, Takayanagi H. Osteoimmunology in bone fracture healing. Curr Osteoporos Rep 2017;15:367-75

136 Uluçkan Özge, Jimenez M, Karbach S, et al. Chronic skin inflammation leads to bone loss by IL-17-mediated inhibition of Wnt signaling in osteoblasts. Sci Trans/ Med 2016:8:330ra37-37

137 Kim Y-G, Park J-W, Lee J-M, et al. IL-17 inhibits osteoblast differentiation and bone regeneration in rat. Arch Oral Biol 2014;59:897-905.

138 Ji R-R, Chamessian A, Zhang Y-Q. Pain regulation by non-neuronal cells and inflammation. Science 2016:354:572-7.

139 Pinho-Ribeiro FA, Verri WA, Chiu IM. Nociceptor sensory Neuron-Immune interactions in pain and inflammation. Trends Immunol 2017:38:5-19.

140 Blachier M, Canouï-Poitrine F, Dougados M, et al. Factors associated with radiographic lesions in early axial spondyloarthritis. Results from the DESIR cohort. Rheumatology 2013;52:1686-93.

141 Wu Q, Inman RD, Davis KD. Neuropathic pain in ankylosing spondylitis: a psychophysics and brain imaging study. Arthritis \& Rheumatism 2013;65:1494-503.

142 Ramjeeawon A, Choy E. 179 Neuropathic-like pain is common in psoriatic arthritis Rheumatology 2018;57(suppl 3). key075.403-key075.403.

143 Richter F, Natura G, Ebbinghaus M, et al. Interleukin-17 sensitizes joint nociceptors to mechanical stimuli and contributes to arthritic pain through neuronal interleukin-17 receptors in rodents. Arthritis Rheum 2012;64:4125-34.

144 Pinto LG, Cunha TM, Vieira SM, et al. IL-17 mediates articular hypernociception in antigen-induced arthritis in mice. Pain 2010;148:247-56.

145 McNamee KE, Alzabin S, Hughes JP, et al. IL-17 induces hyperalgesia via TNFdependent neutrophil infiltration. Pain 2011;152:1838-45.

146 Meng X, Zhang Y, Lao L, et al. Spinal interleukin-17 promotes thermal hyperalgesia and NMDA NR 1 phosphorylation in an inflammatory pain rat model. Pain 2013; 154:294-305. 
147 Das Sarma J, Ciric B, Marek R, et al. Functional interleukin-17 receptor A is expressed in central nervous system glia and upregulated in experimental autoimmune encephalomyelitis. J Neuroinflammation 2009;6.

148 Hu Y, Ota N, Peng I, et al. IL-17RC is required for IL-17A- and IL-17F-dependent signaling and the pathogenesis of experimental autoimmune encephalomyelitis. J Immunol 2010;184:4307-16.

149 Cao L, DeLeo JA. CNS-infiltrating CD4+ T lymphocytes contribute to murine spinal nerve transection-induced neuropathic pain. Eur J Immunol 2008;38:448-58.

150 Costigan M, Moss A, Latremoliere A, et al. T-cell infiltration and signaling in the adult dorsal spinal cord is a major contributor to neuropathic pain-like hypersensitivity. J Neurosci 2009;29:14415-22.

151 Olechowski CJ, Truong JJ, Kerr BJ. Neuropathic pain behaviours in a chronicrelapsing model of experimental autoimmune encephalomyelitis (EAE). Pain 2009;141:156-64.

152 Sun C, Zhang J, Chen L, et al. IL-17 contributed to the neuropathic pain following peripheral nerve injury by promoting astrocyte proliferation and secretion of proinflammatory cytokines. Mol Med Rep 2017:15:89-96.

153 Deodhar A, Conaghan PG, Kvien TK, et al. Secukinumab provides rapid and persistent relief in pain and fatigue symptoms in patients with ankylosing spondylitis irrespective of baseline C-reactive protein levels or prior tumour necrosis factor inhibitor therapy: 2-year data from the measure 2 study. Clin Exp Rheumatol 2019;37:260-9.

154 Mclnnes IB, Mease PJ, Schett G, et al. Secukinumab provides rapid and sustained pain relief in psoriatic arthritis over 2 years: results from the FUTURE 2 study. Arthritis Res Ther 2018;20.

155 Hundorfean G, Neurath MF, Mudter J. Functional relevance of T helper 17 (Th17) cells and the IL-17 cytokine family in inflammatory bowel disease. Inflamm Bowel Dis 2012:18:180-6.

156 Khanna PV, Shih DQ, Haritunians T, et al. Use of animal models in elucidating disease pathogenesis in IBD. Semin Immunopathol 2014:36:541-51.

157 Schreiber S, Colombel J-F, Feagan BG, et al. Incidence rates of inflammatory bowel disease in patients with psoriasis, psoriatic arthritis and ankylosing spondylitis treated with secukinumab: a retrospective analysis of pooled data from 21 clinical trials. Ann Rheum Dis 2019;78:473-9.

158 Lee JS, Tato CM, Joyce-Shaikh B, et al. Interleukin-23-independent IL-17 production regulates intestinal epithelial permeability. Immunity 2015;43:727-38

159 Ivanov II, Atarashi K, Manel N, et al. Induction of intestinal Th17 cells by segmented filamentous bacteria. Cell 2009;139:485-98.

160 Niess JH, Leithäuser F, Adler G, et al. Commensal gut flora drives the expansion of proinflammatory CD4 T cells in the colonic lamina propria under normal and inflammatory conditions. J Immuno/ 2008;180:559-68.

161 Mortier C, Govindarajan S, Venken K, et al. It Takes "Guts" to Cause Joint Inflammation: Role of Innate-Like T Cells. Front Immunol 2018;9.

162 Shih VF-S, Cox J, Kljavin NM, et al. Homeostatic IL-23 receptor signaling limits Th17 response through IL-22-mediated containment of commensal microbiota. Proceedings of the National Academy of Sciences 2014;111:13942-7.

163 Qiu J, Guo X, Chen Z-ME, et al. Group 3 innate lymphoid cells inhibit T-cell-mediated intestinal inflammation through aryl hydrocarbon receptor signaling and regulation of microflora. Immunity 2013;39:386-99.

164 Ciccia F, Guggino G, Rizzo A, et al. Type 3 innate lymphoid cells producing IL-17 and IL-22 are expanded in the gut, in the peripheral blood, synovial fluid and bone marrow of patients with ankylosing spondylitis. Ann Rheum Dis 2015;74:1739-47

165 Manfredo Vieira S, Hiltensperger M, Kumar V, et al. Translocation of a gut pathobiont drives autoimmunity in mice and humans. Science 2018;359:1156-61.

166 Weinstein JE, Pepple KL. Cytokines in uveitis. Curr Opin Ophthalmol 2018:29:267-74.

167 Deodhar A, Miceli-Richard C, Baraliakos X, et al. Low incidence of both new-onset and flares of uveitis in secukinumab-treated patients with ankylosing spondylitis: clinical trial and post-marketing safety analysis (Abstract SAT0270). Ann Rheum Dis 2018:77:999

168 Thaçi D, Blauvelt A, Reich K, et al. Secukinumab is superior to ustekinumab in clearing skin of subjects with moderate to severe plaque psoriasis: clear, a randomized controlled trial. J Am Acad Dermatol 2015:73:400-9.

169 van der Heijde D, Cheng-Chung Wei J, Dougados M, et al. Ixekizumab, an interleukin-17A antagonist in the treatment of ankylosing spondylitis or radiographic axial spondyloarthritis in patients previously untreated with biological disease-modifying anti-rheumatic drugs (COAST-V): 16 week results of a phase 3 randomised, double-blind, active-controlled and placebo-controlled trial. The Lancet 2018:392:2441-51.

170 Deodhar A, Poddubnyy D, Pacheco-Tena C, et al. Efficacy and Safety of Ixekizumab in the Treatment of Radiographic Axial Spondyloarthritis: Sixteen-Week Results From a Phase III Randomized, Double-Blind, Placebo-Controlled Trial in Patients With Prior Inadequate Response to or Intolerance of Tumor Necrosis Factor Inhibitors. Arthritis Rheumatol 2019:71:599-611.

171 Deodhar A, Gensler LS, Sieper J, et al. Three multicenter, randomized, double-blind, placebo-controlled studies evaluating the efficacy and safety of ustekinumab in axia spondyloarthritis. Arthritis Rheumatol 2019;71:258-70.
172 Baeten D, Østergaard M, Wei JC-C, et al. Risankizumab, an IL-23 inhibitor, for ankylosing spondylitis: results of a randomised, double-blind, placebocontrolled, proof-of-concept, dose-finding phase 2 study. Ann Rheum Dis 2018;77:1295-302

173 McGonagle D, Lories RJU, Tan AL, et al. The concept of a "synovio-entheseal complex" and its implications for understanding joint inflammation and damage in psoriatic arthritis and beyond. Arthritis Rheum 2007;56:2482-91.

174 Castillo-Gallego C, Aydin SZ, Emery P, et al. Magnetic resonance imaging assessment of axial psoriatic arthritis: extent of disease relates to HLA-B27. Arthritis Rheum 2013;65:2274-8

175 van Tok MN, Na S, Lao CR, et al. The initiation, but not the persistence, of experimental spondyloarthritis is dependent on interleukin-23 signaling. Front Immunol 2018;9.

176 Fieschi C, Bosticardo M, de Beaucoudrey L, et al. A novel form of complete IL-12/ IL-23 receptor beta1 deficiency with cell surface-expressed nonfunctional receptors. Blood 2004;104:2095-101.

177 Fieschi C, Casanova J-L. The role of interleukin-12 in human infectious diseases: only a faint signature. Eur J Immunol 2003;33:1461-4.

178 Fieschi C, Dupuis S, Catherinot E, et al. Low penetrance, broad resistance, and favorable outcome of interleukin 12 receptor beta 1 deficiency: medical and immunological implications. J Exp Med 2003;197:527-35.

179 Ouederni M, Sanal O, Ikincioğullari A, et al. Clinical features of candidiasis in patients with inherited interleukin 12 receptor $\beta 1$ deficiency. Clin Infect Dis 2014;58:204-13.

180 Ramirez-Alejo N, Blancas-Galicia L, Yamazaki-Nakashimada M, et al. Molecular analysis for patients with IL-12 receptor $\beta 1$ deficiency. Clin Genet 2014;86:161-6.

181 Bustamante J, Boisson-Dupuis S, Jouanguy E, et al. Novel primary immunodeficiencies revealed by the investigation of paediatric infectious diseases. Curr Opin Immunol 2008;20:39-48.

182 Boisson B, Wang C, Pedergnana V, et al. An ACT1 mutation selectively abolishes interleukin-17 responses in humans with chronic mucocutaneous candidiasis. Immunity 2013;39:676-86.

183 Boisson-Dupuis S, Kong X-F, Okada S, et al. Inborn errors of human STAT1: Allelic heterogeneity governs the diversity of immunological and infectious phenotypes. Curr Opin Immunol 2012:24:364-78.

184 Altare F, Durandy A, Lammas D, et al. Impairment of mycobacterial immunity in human interleukin-12 receptor deficiency. Science 1998;280:1432-5.

185 Akahoshi M, Nakashima H, Miyake K, et al. Influence of interleukin-12 receptor beta1 polymorphisms on tuberculosis. Hum Genet 2003;112:237-43.

186 Al-Muhsen S, Casanova J-L. The genetic heterogeneity of Mendelian susceptibility to mycobacterial diseases. J Allergy Clin Immunol 2008;122:1043-51.

187 de Beaucoudrey L, Samarina A, Bustamante J, et al. Revisiting human IL-12Rß1 deficiency: a survey of 141 patients from 30 countries. Medicine 2010;89:381-402.

188 MacLennan C, Fieschi C, Lammas DA, et al. Interleukin (IL)-12 and IL-23 are key cytokines for immunity against Salmonella in humans. $J$ Infect Dis 2004;190:1755-7.

189 Godinez I, Keestra AM, Spees A, et al. The IL-23 axis in Salmonella gastroenteritis. Cell Microbiol 2011;13:1639-47.

190 de Jong R, Altare F, Haagen IA, et al. Severe mycobacterial and Salmonella infections in interleukin-12 receptor-deficient patients. Science 1998;280:1435-8.

191 Puel A, Cypowyj S, Bustamante J, et al. Chronic mucocutaneous candidiasis in humans with inborn errors of interleukin-17 immunity. Science 2011;332:65-8.

192 Ling Y, Cypowyj S, Aytekin C, et al. Inherited IL-17RC deficiency in patients with chronic mucocutaneous candidiasis. J Exp Med 2015;212:619-31.

193 Bader O, Weig MS, Gross U, et al. Photo quiz. A 32-year-old man with ulcerative mucositis, skin lesions, and nail dystrophy. Chronic mucocutaneous candidiasis by multidrug-resistant Candida albicans. Clin Infect Dis 2012;54:1035-6.

194 Kisand K, Bøe Wolff AS, Podkrajšek KT, et al. Chronic mucocutaneous candidiasis in APECED or thymoma patients correlates with autoimmunity to Th17-associated cytokines. J Exp Med 2010;207:299-308.

195 Kisand K, Lilic D, Casanova J-L, et al. Mucocutaneous candidiasis and autoimmunity against cytokines in APECED and thymoma patients: clinical and pathogenetic implications. Eur J Immunol 2011;41:1517-27.

196 Aaltonen J, Björses P, Perheentupa J, et al. An autoimmune disease, APECED, caused by mutations in a novel gene featuring two PHD-type zinc-finger domains. Nat Genet 1997:17:399-403.

197 Nagamine K, Peterson P, Scott HS, et al. Positional cloning of the APECED gene. Nat Genet 1997:17:393-8.

198 Freeman AF, Holland SM. The hyper-IgE syndromes. Immunol Allergy Clin North Am 2008:28:277-91.

199 Renner ED, Rylaarsdam S, Aňover-Sombke S, et al. Novel signal transducer and activator of transcription 3 (STAT3) mutations, reduced $\mathrm{T}(\mathrm{H}) 17$ cell numbers, and variably defective STAT3 phosphorylation in hyper-lgE syndrome. J Allergy Clin Immunol 2008:122:181-7.

200 Ma CS, Chew GYJ, Simpson N, et al. Deficiency of Th17 cells in hyper IgE syndrome due to mutations in STAT3. J Exp Med 2008;205:1551-7.

201 Minegishi Y, Saito M, Tsuchiya S, et al. Dominant-negative mutations in the DNAbinding domain of STAT3 cause hyper-IgE syndrome. Nature 2007;448:1058-62. 
202 Drewniak A, Gazendam RP, Tool ATJ, et al. Invasive fungal infection and impaired neutrophil killing in human CARD9 deficiency. Blood 2013;121:2385-92.

203 Engelhardt KR, McGhee S, Winkler S, et al. Large deletions and point mutations involving the dedicator of cytokinesis 8 (DOCK8) in the autosomal-recessive form of hyper-IgE syndrome. J Allergy Clin Immunol 2009;124:1289-302.

204 Lee YH, Song GG. Associations between interleukin-23R polymorphisms and ankylosing spondylitis susceptibility: an updated meta-analysis. Z Rheumatol 2019:78:272-80.

205 Yang B, Xu Y, Liu X, et al. IL-23R and IL-17A polymorphisms correlate with susceptibility of ankylosing spondylitis in a southwest Chinese population. Oncotarget 2017;8:70310-6.

206 Zhong L, Wang W, Song H. Complex role of IL-23R polymorphisms on ankylosing spondylitis: a meta-analysis. Expert Rev Clin Immunol 2018;14:635-43.

207 Chen C, Zhang X, Wang Y. ANTXR2 and IL-1R2 polymorphisms are not associated with ankylosing spondylitis in Chinese Han population. Rheumatol Int 2012;32:15-19.

208 Rocha Loures MA, Macedo LC, Reis DM, et al. Influence of TNF and IL17 Gene Polymorphisms on the Spondyloarthritis Immunopathogenesis, Regardless of HLA-B27, in a Brazilian Population. Mediators Inflamm 2018;2018:1-7.

209 Vidal-Castiñeira JR, López-Vázquez A, Diaz-Peña R, et al. A single nucleotide polymorphism in the II17ra promoter is associated with functional severity of ankylosing spondylitis. PLoS One 2016;11:e0158905.

210 Nossent JC, Sagen-Johnsen S, Bakland G. IL23R gene variants in relation to IL17A levels and clinical phenotype in patients with ankylosing spondylitis. Rheumatol Adv Pract 2018;2

211 Reveille JD, Sims A-M, Danoy P, et al. Genome-wide association study of ankylosing spondylitis identifies non-MHC susceptibility loci. Nat Genet 2010:42:123-7.

212 Karaderi T, Harvey D, Farrar C, et al. Association between the interleukin 23 receptor and ankylosing spondylitis is confirmed by a new UK case-control study and metaanalysis of published series. Rheumatology 2009;48:386-9.

213 Dong H, Li Q, Zhang Y, et al. IL23R gene confers susceptibility to ankylosing spondylitis concomitant with uveitis in a Han Chinese population. PLoS One 2013;8:e67505.

214 Wang X, Huang J, Lin Z, et al. Single-nucleotide polymorphisms and expression of IL23R in Chinese ankylosing spondylitis patients. Rheumatol Int 2010;30:955-9.

215 Sáfrány E, Pazár B, Csöngei V, et al. Variants of the IL23R gene are associated with ankylosing spondylitis but not with Sjögren syndrome in Hungarian population samples. Scand J Immunol 2009;70:68-74.

216 Roberts AR, Vecellio M, Cortes A, et al. Investigation of a possible extended risk haplotype in the IL23R region associated with ankylosing spondylitis. Genes Immun 2017:18:105-8.

217 Xia Y, Liu Y-Q, Chen K, et al. Association of IL-1R2 genetic polymorphisms with the susceptibility of ankylosing spondylitis in northern Chinese Han population. Mod Rheumatol 2015;25:908-12.

218 Kenna TJ, Davidson SI, Duan R, et al. Enrichment of circulating interleukin-17secreting interleukin-23 receptor-positive $\gamma / \delta \mathrm{T}$ cells in patients with active ankylosing spondylitis. Arthritis Rheum 2012;64:1420-9.

219 Guggino G, Ciccia F, Di Liberto D, et al. Interleukin (IL)-9/IL-9R axis drives $\gamma \delta$ T cells activation in psoriatic arthritis patients. Clin Exp Immunol 2016;186:277-83.

220 Chowdhury AC, Chaurasia S, Mishra SK, et al. IL-17 and IFN- $\gamma$ producing NK and $\gamma \delta$-T cells are preferentially expanded in synovial fluid of patients with reactive arthritis and undifferentiated spondyloarthritis. Clin Immunol 2017;183:207-12.

221 Cai Y, Shen X, Ding C, et al. Pivotal role of dermal IL-17-producing $\gamma \delta \mathrm{T}$ cells in skin inflammation. Immunity 2011:35:596-610.

222 Campbell JJ, Ebsworth K, Ertl LS, et al. IL-17-Secreting $\gamma \delta$ T cells are completely dependent upon CCR6 for homing to inflamed skin. J.i. 2017;199:3129-36.

223 Gravallese EM, Schett G. Effects of the IL-23-IL-17 pathway on bone in spondyloarthritis. Nat Rev Rheumatol 2018:14:631-40.

224 Leipe J, Grunke M, Dechant C, et al. Role of Th17 cells in human autoimmune arthritis. Arthritis Rheum 2010:62:2876-85.

225 Xueyi L, Lina C, Zhenbiao W, et al. Levels of circulating Th17 cells and regulatory T cells in ankylosing spondylitis patients with an inadequate response to anti-TNF- $\alpha$ therapy. J Clin Immunol 2013;33:151-61.

226 Zizzo G, De Santis M, Bosello SL, et al. Synovial fluid-derived T helper 17 cells correlate with inflammatory activity in arthritis, irrespectively of diagnosis. Clin Immunol 2011;138:107-16.

227 Ortega C, Fernández-A S, Carrillo JM, et al. IL-17-producing CD8+ $T$ lymphocytes from psoriasis skin plaques are cytotoxic effector cells that secrete Th17-related cytokines. J Leukoc Biol 2009;86:435-43.
228 Hijnen D, Knol EF, Gent YY, et al. CD8(+) T cells in the lesional skin of atopic dermatitis and psoriasis patients are an important source of IFN- $\gamma, \mathrm{IL}-13, \mathrm{IL}-17$, and IL-22. J Invest Dermatol 2013;133:973-9.

229 Steel KJA, S-Y W, Srenathan U, et al. Synovial IL-17+ CD8+ T cells are a proinflammatory tissue resident population enriched in spondyloarthritis (Abstract 0016). Ann Rheum Dis 2018:77:A8-A9.

230 Di Meglio P, Villanova F, Navarini AA, et al. Targeting CD8(+) T cells prevents psoriasis development. J Allergy Clin Immunol 2016;138:274-6.

231 Rahman MS, Akhtar N, Jamil HM, et al. TGF- $\beta$ /BMP signaling and other molecular events: regulation of osteoblastogenesis and bone formation. Bone Res 2015;3.

232 ClinicalTrialsgov. Study of the efficacy and safety of Secukinumab in participants with active psoriatic arthritis with axial skeleton involvement (maximise. National Institute of Health US National Library of Medicine, 2018.

233 Braun J, Baraliakos X, Deodhar A, et al. Effect of secukinumab on clinical and radiographic outcomes in ankylosing spondylitis: 2-year results from the randomised phase III measure 1 study. Ann Rheum Dis 2017;76:1070-7.

234 ClinicalTrialsgov. NCT02696031: study of efficacy and safety of Secukinumab in patients with non-radiographic axial spondyloarthritis. National Institute of Health US National Library of Medicine, 2018.

235 Novartis. Cosentyx: EPAR - Product Information, 2017. Available: http://www.ema. europa.eu/ema/index.jsp?curl=pages/medicines/human/medicines/003729/human_ med_001832.jsp\&mid=WC0b01ac058001d124

236 ClinicalTrialsgov. NCT02757352: a study of ixekizumab (LY2439821) in participants with Nonradiographic axial spondyloarthritis (COAST-X), 2018. National Institute of health us National Library of medicine. Available: https://clinicaltrials.gov/ct2/show/ NCT02757352

237 Lilly. Taltz EPAR, 2019. Available: https://www.ema.europa.eu/documents/productinformation/taltz-epar-product-information en.pdf

238 Sieper J, Braun J, Dougados M, et al. Axial spondyloarthritis. Nat Rev Dis Primers 2015;1.

239 Mclnnes IB, Kavanaugh A, Gottlieb AB, et al. Efficacy and safety of ustekinumab in patients with active psoriatic arthritis: 1 year results of the phase 3, multicentre, double-blind, placebo-controlled PSUMMIT 1 trial. Lancet 2013:382:780-9.

240 Ritchlin C, Rahman P, Kavanaugh A, et al. Efficacy and safety of the anti-IL-12/23 p40 monoclonal antibody, ustekinumab, in patients with active psoriatic arthritis despite conventional non-biological and biological anti-tumour necrosis factor therapy: 6-month and 1-year results of the phase 3, multicentre, double-blind, placebo-controlled, randomised PSUMMIT 2 trial. Ann Rheum Dis 2014;73:990-9.

241 Leonardi CL, Kimball AB, Papp KA, et al. Efficacy and safety of ustekinumab, a human interleukin-12/23 monoclonal antibody, in patients with psoriasis: 76-week results from a randomised, double-blind, placebo-controlled trial (Phoenix 1). The Lancet 2008:371:1665-74.

242 Griffiths CEM, Strober BE, van de Kerkhof P, et al. Comparison of ustekinumab and etanercept for moderate-to-severe psoriasis. N Engl J Med 2010;362:118-28.

243 Reich K, Armstrong AW, Foley P, et al. Efficacy and safety of guselkumab, an anti-interleukin-23 monoclonal antibody, compared with adalimumab for the treatment of patients with moderate to severe psoriasis with randomized withdrawal and retreatment: results from the phase III, double-blind, placebo- and active comparator-controlled voyage 2 trial. J Am Acad Dermatol 2017;76:418-31.

244 Gordon KB, Strober B, Lebwohl M, et al. Efficacy and safety of risankizumab in moderate-to-severe plaque psoriasis (UltIMMa-1 and UltIMMa-2): results from two double-blind, randomised, placebo-controlled and ustekinumab-controlled phase 3 trials. The Lancet 2018;392:650-61.

245 Blauvelt A, Papp KA, Griffiths CEM, et al. Efficacy and safety of guselkumab, an antiinterleukin-23 monoclonal antibody, compared with adalimumab for the continuous treatment of patients with moderate to severe psoriasis: results from the phase III, double-blinded, placebo- and active comparator-controlled voyage 1 trial. J Am Acad Dermatol 2017;76:405-17

246 van der Heijde D, Kivitz A, Schiff MH, et al. Efficacy and safety of adalimumab in patients with ankylosing spondylitis: results of a multicenter, randomized, doubleblind, placebo-controlled trial. Arthritis Rheum 2006;54:2136-46.

247 Mease PJ, Gladman DD, Ritchlin CT, et al. Adalimumab for the treatment of patients with moderately to severely active psoriatic arthritis: results of a double-blind, randomized, placebo-controlled trial. Arthritis Rheum 2005:52:3279-89.

248 Menter A, Tyring SK, Gordon K, et al. Adalimumab therapy for moderate to severe psoriasis: a randomized, controlled phase III trial. J Am Acad Dermatol 2008;58:106-15.

249 Yoshiga Y, Goto D, Segawa S, et al. Invariant NKT cells produce IL-17 through IL-23dependent and -independent pathways with potential modulation of Th17 response in collagen-induced arthritis. Int J Mol Med 2008:22:369-74. 


\section{Correction: The role of IL-17A in axial spondyloarthritis and psoriatic arthritis: recent advances and controversies. A meta- analysis and functional study}

McGonagle DG, McInnes IB, Kirkham BW, et al. The role of IL-17A in axial spondyloarthritis and psoriatic arthritis: recent advances and controversies. A meta-analysis and functional study. Ann of Rheum Dis 2019;78:1167-78. doi: 10.1136/annrheumdis-2019-215356.

Figure 4 is amended to reflect the lack of definitive, controlled clinical evidence of prevention of structural progression by secukinumab in axial spondyloarthritis.

\begin{tabular}{|c|c|c|}
\hline & Secukinumab ${ }^{12-16.20,21,188,232-225}$ & Ixekizumab ${ }^{17-19,169,236,237}$ \\
\hline Approved indications & Psoriasis, PsA, AS & Psoriasis, PsA \\
\hline MoA & Fully-human anti-IL-17A antibody & Humanised anti-IL-17A antibody \\
\hline \multicolumn{3}{|l|}{ PsA } \\
\hline Peripheral arthritis & - & - \\
\hline Enthesitis & - & - \\
\hline Dactylitis & - & - \\
\hline Skin & - & - \\
\hline Nail & - & - \\
\hline Axial disease & ○ & 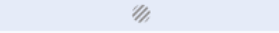 \\
\hline Structural progression & - & - \\
\hline \multicolumn{3}{|l|}{ AS } \\
\hline Signs and symptoms & - & - \\
\hline Disease activity & - & - \\
\hline Function & - & - \\
\hline Structural progression & ○ & ○ \\
\hline Non-radiographic axial SpA & P & O \\
\hline Psoriasis & - & ○ \\
\hline Crohn's disease & - & 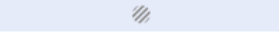 \\
\hline Uveitis ${ }^{\circ}$ & $\Rightarrow$ & 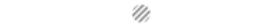 \\
\hline
\end{tabular}

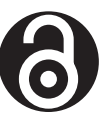

\section{OPEN ACCESS}

Open access This is an open access article distributed in accordance with the Creative Commons Attribution Non Commercial (CC BY-NC 4.0) license, which permits others to distribute, remix, adapt, build upon this work noncommercially, and license their derivative works on different terms, provided the original work is properly cited, appropriate credit is given, any changes made indicated, and the use is non-commercial. See: http://creativecommons.org/licenses/by-nc/ 4.0\%.

(C) Author(s) (or their employer(s)) 2020. Re-use permitted under CC BY-NC. No commercial re-use. See rights and permissions. Published by BMJ.

Ann Rheum Dis 2020;79. doi:10.1136/annrheumdis-2019-215356corr1

Check for updates 